\title{
Review
}

\section{The Unique Biology behind the Early Onset of Breast Cancer}

\author{
Alaa Siddig ${ }^{1}\left(\mathbb{D}\right.$, Tengku Ahmad Damitri Al-Astani Tengku Din ${ }^{2,3}$, Siti Norasikin Mohd Nafi ${ }^{1}$, \\ Maya Mazuwin Yahya ${ }^{3,4}$, Sarina Sulong ${ }^{5}$ and Wan Faiziah Wan Abdul Rahman 1,3,*(D)
}

1 Department of Pathology, School of Medical Sciences, Health Campus, Universiti Sains Malaysia, Kelantan 16150, Malaysia; alaaabdelaziz@student.usm.my (A.S.); snmn@usm.my (S.N.M.N.)

2 Department of Chemical Pathology, School of Medical Sciences, Health Campus, Universiti Sains Malaysia, Kelantan 16150, Malaysia; damitri@usm.my

3 Breast Cancer Awareness \& Research Unit, Hospital Universiti Sains Malaysia, Kelantan 16150, Malaysia; mazuwin@usm.my

4 Department of Surgery, School of Medical Sciences, Health Campus, Universiti Sains Malaysia, Kelantan 16150, Malaysia

5 Human Genome Centre, School of Medical Sciences, Health Campus, Universiti Sains Malaysia, Kelantan 16150, Malaysia; ssarina@usm.my

* Correspondence: wfaiziah@usm.my; Tel.: +609-7676193

Citation: Siddig, A.; Tengku Din

T.A.D.A.-A.; Mohd Nafi, S.N.; Yahya, M.M.; Sulong, S.; Wan Abdul Rahman, W.F. The Unique Biology behind the Early Onset of Breast Cancer. Genes 2021, 12, 372. https:// doi.org/10.3390/genes12030372

Academic Editor: Carmen Criscitiello

Received: 1 February 2021

Accepted: 2 March 2021

Published: 5 March 2021

Publisher's Note: MDPI stays neutral with regard to jurisdictional claims in published maps and institutional affiliations.

Copyright: (c) 2021 by the authors. Licensee MDPI, Basel, Switzerland. This article is an open access article distributed under the terms and conditions of the Creative Commons Attribution (CC BY) license (https:// creativecommons.org/licenses/by/ $4.0 /)$.

\begin{abstract}
Breast cancer commonly affects women of older age; however, in developing countries, up to $20 \%$ of breast cancer cases present in young women (younger than 40 years as defined by oncology literature). Breast cancer in young women is often defined to be aggressive in nature, usually of high histological grade at the time of diagnosis and negative for endocrine receptors with poor overall survival rate. Several researchers have attributed this aggressive nature to a hidden unique biology. However, findings in this aspect remain controversial. Thus, in this article, we aimed to review published work addressing somatic mutations, chromosome copy number variants, single nucleotide polymorphisms, differential gene expression, microRNAs and gene methylation profile of early-onset breast cancer, as well as its altered pathways resulting from those aberrations. Distinct biology behind early-onset of breast cancer was clear among estrogen receptor-positive and sporadic cases. However, further research is needed to determine and validate specific novel markers, which may help in customizing therapy for this group of patients.
\end{abstract}

Keywords: early-onset breast cancer; differential gene expression; somatic mutations; breast cancer in young age; copy number variants; gene methylation; extracellular matrix protein-coding genes

\section{Introduction}

Breast cancer has been identified as the most common cancer among women worldwide with an estimated two million new cancer cases diagnosed in 2018, accounting for $23 \%$ of all cancer types [1]. Breast cancer is a disease characterized by having diverse clinical behaviors and different biological characteristics, making the process of prediction and management more challenging for physicians, breast surgeons, and oncologists [2]. Advancement in molecular technologies revealed that breast cancer is not a single disease, but is a group of conditions with distinct molecular profiles [3]. Predominantly, breast cancer affects women older than 40 years. Yet, in some parts of the world such as in Eastern Asia, the Middle East, North Africa, and South America, breast cancer in young women ( $<40$ years) had high frequencies [4]. Incidence of early-onset breast cancer (EOBC) was estimated to reach $6 \%-10 \%$ of all breast cancer cases in developed countries; this figure doubled in developing countries where the percentage reaches $20 \%$; the same goes for its mortality rate, that is, $7 \%$ vs. $14 \%$ for developed and developing countries, respectively [5].

Breast cancer in young women has been defined by its aggressive nature; it tends to be of high histological grade at diagnosis, high proliferation rate, and is positive for human epidermal growth factor receptor (HER-2) and negative for endocrine receptors. 
In addition, high rate of local recurrence was associated with EOBC [6-14]. Kataoka A. et al. found that after adjusting several prognostic factors including nodal status, adjuvant therapy, and breast cancer subtype, young age remained an independent negative prognostic factor for poor prognosis for all three endpoints: 5-year disease-free survival, breast cancer-specific survival, and overall survival [15]. Many researchers assumed that $\mathrm{EOBC}$ has distinct biology different from that in late-onset. In their view, this distinction is not only observed in the aggressive phenotype mentioned above, but also in the different distributions of risk factors and the contradictory clinical outcome of patients with comparable clinicopathological parameters and similar therapeutic approach but the only difference is that they belong to different age groups [16,17].

In this article, we reviewed published literature addressing EOBC-related somatic mutations, chromosome copy number variants, single nucleotide polymorphism, differential gene expression profile, microRNAs, DNA methylation profile, and differentially expressed proteins, as well as altered pathways that have resulted from those aberrations. We believe that better understanding of EOBC biology may help in the identification and verification of molecular markers, which is a step towards personalizing therapy for this group of patients who show insufficient efficacy to conventional adjuvant hormone and chemotherapy.

\section{Contribution of Common Breast Cancer Mutations}

Germline mutations acquired in DNA repair and tumor suppressor genes are the most common form of breast cancer genetic susceptibility, which ultimately lead to the accumulation of mutations in cell cycle check point and oncogenes that are required for aberrant cell division [18]. Around 10\%-20\% of EOBC cases are hereditary [19] BRCA1 and $B R C A 2$ are the most common mutated genes related to breast cancer since their discovery in the early 1990s [20]. Mutations related to the development of cancers are often classified as high, intermediate, and low penetrance mutation based on their relative risk for the specific cancer. BRCA1, BRCA2, TP53, PTEN, STK11, and CDH1 are considered the high penetrance mutations of breast cancer where they account for $20 \%$ of hereditary risk. This is followed by moderate penetrance mutations, which include PALB2, BRIP1, ATM, CHEK2, and $R A D 51 C$, which account for around $5 \%$ of hereditary risk [21]. In addition, more than 180 mutations are considered as low-risk loci for breast cancer, which explains only $18 \%$ of the familial risk. All these relative risk proportions define only half of the genetic risk of breast cancer, with the other half still unknown [22]. In this study, we found that the relative risk of different mutations differs among different age groups. In Table 1. we provide a summary of the contributions of common breast cancer mutations to EOBC. 
Table 1. Contribution of common breast cancer mutations to early-onset breast cancer (EOBC).

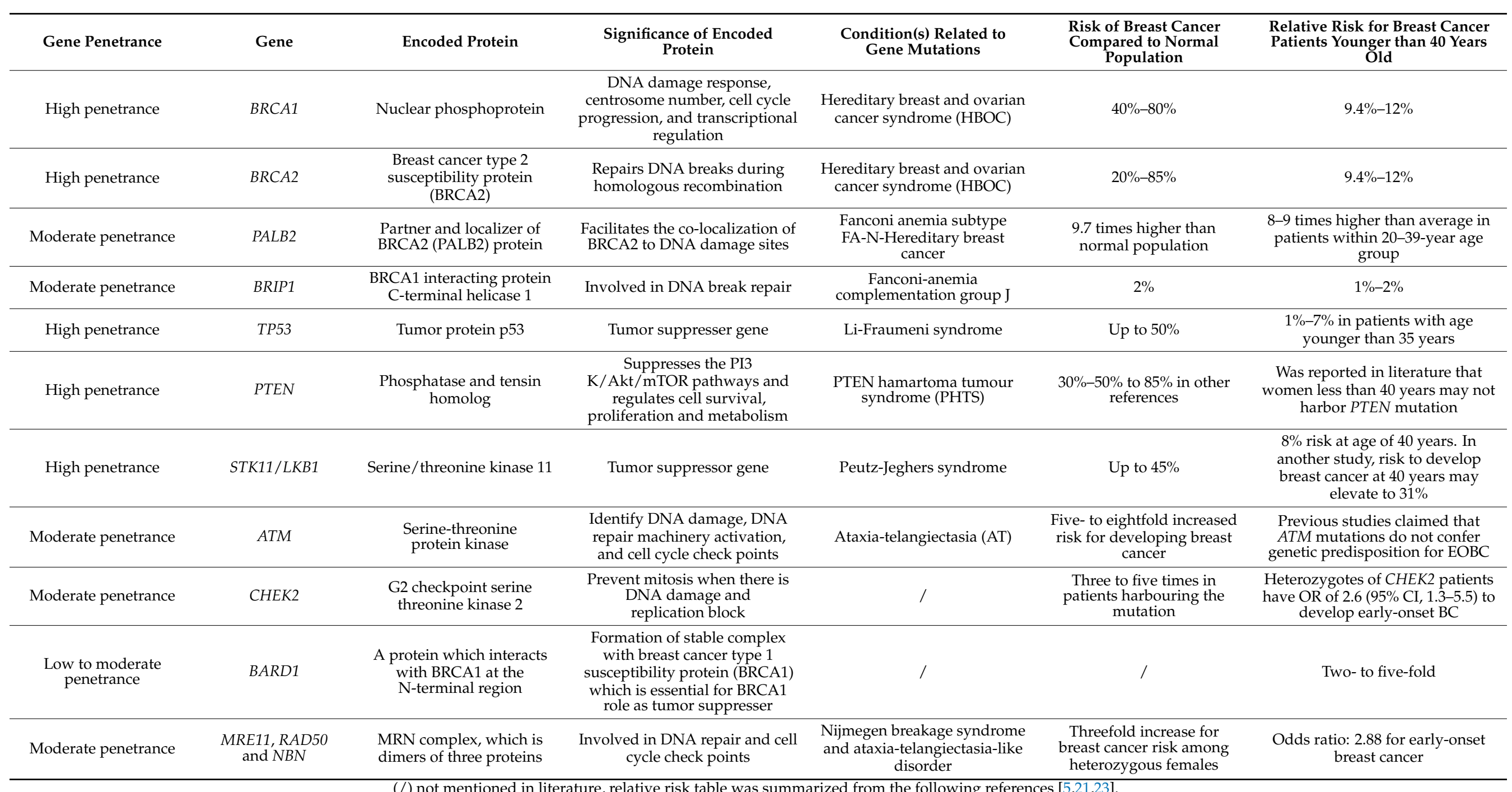




\section{Prevalence of $B R C A 1$ and $B R C A 2$ Mutations}

$B R C A 1$ mutations were attributed to the high frequency of triple-negative and highgrade tumors seen in EOBC [24]. However, the frequency of $B R C A 1$ mutations among different populations has been found to vary widely $(5.9 \%, 22.7 \%, 12 \%, 12.2 \%$, and $6.2 \%$ among British, Italian, American, Polish, and Chinese, respectively) [25-29], and still aggressive characteristics of EOBC persist. Conversely, $B R C A 2$ mutations show less contribution to $\mathrm{EOBC}$, and, even if detected, it does not appear to correlate with the aggressive phenotype (high-grade, negative estrogen and progesterone receptor, high proliferation rate). Thus, in-depth investigation should be conducted among heterogeneous EOBC cohort to reveal the shared mutational pattern and frequency of $B R C A 1$.

\section{Somatic Mutations}

In 2017, Bryan et al. proved that no germline mutations were associated with the mortality rate and aggressive nature of EOBC [30], directing later research towards somatic and transcriptomic variations. Using The Cancer Genome Atlas (TCGA) and Molecular Taxonomy of Breast Cancer International Consortium (METABRIC) databases, young age estrogen receptor-positive breast cancer patients ( $\leq 45$ years) showed high mutational rate in $C D H 1$ gene in comparison to older age patients ( $\geq 55$ years) ( $14.5 \%$ vs. $2.9 \%$ ). It should be noted that $C D H 1$ mutations are common findings in lobular breast carcinoma, which mostly affects older age patients. However, in this study, CDH1 mutations were found to be significantly high among young age patients even after amendment for multiple comparisons [31]. This may suggest a shared mutational profile between lobular carcinoma and EOBC. $C D H 1$ gene encodes E-cadherin protein, which plays a significant role in cell-cell adhesion as well as cell-extracellular matrix adhesion [32]. Disturbed expression of E-cadherin was found to be associated with high-grade tumor, metastasis, and poor prognosis [33].

Meanwhile, another two groups of researchers used TCGA public database to determine the landscape of somatic mutations in EOBC. The first group of researchers found that GATA3 mutations were the only somatic mutations independently associated with young age patients ( $<45$ years) compared to older age patients ( $>46$ years) even after adjustment of several clinicopathological parameters [34]. The second group reported high proportion of mutations in GATA3 and CTNNB1 genes in EOBC patients ( $\leq 40$ years) compared to late-onset patients ( $>40$ years) [35]. Understanding the role of GATA3 and CTNNB1 genes may help in recognizing their contribution to EOBC. In addition to the main role of GATA3 in mammary gland development [36], GATA3 is also known to encode a transcription factor involved in T-cell differentiation [37]. Tumors with low GATA binding protein 3 (GATA3) expression levels were found to be associated with shorter overall and diseasefree survival compared to tumors with high GATA3 expression levels [38]. In summary, GATA3 mutations contribute to cancer initiation, resistance to endocrine therapy, and poor prognosis [39]. On the other hand, CTNNB1 gene encodes $\beta$-catenin protein, which is an important protein for intercellular structure and cell growth modulation. $\beta$-Catenin has been determined to be vital in cell-cell adhesion. Disturbance in $\beta$-catenin expression may result in tumor metastasis [40].

In a recent study that examined 90 Taiwanese women with EOBC ( $<41$ years), whole genome sequencing and whole exon sequencing revealed that $40 \%$ and $37 \%$ of patients were harboring mutations in tumor suppressor gene TP53 and oncogene PIK3CA, respectively. The unexpected findings were the high frequency of extracellular structural protein-coding gene mutations MUC17 (19\%), TTN (17\%), and FLG (16\%). Comparing the frequencies of the three mutations between non-Taiwanese pooled EOBC and pooled non-EOBC cohorts, MUC17 and FLG mutations were found to remain distinctly high [41]. Little is known about MUC17 implications for breast cancer. However, it is important to note that MUC1 and MUC4 have been reported to induce chemoresistance, possibly through creating physical barrier minimizing tumoral drug concentration or by reducing apoptosis [42]. Al Amri et al. presented MUC17 expression as chemotherapy predictive markers in breast 
cancer; further, in vitro knockdown of MUC17 was associated with enhanced chemotherapy sensitivity. Moreover, survival analysis showed that low level of MUC17 expression was related to longer survival following chemotherapy [43]. On the other hand, protein encoded by Filaggrin ( $F L G)$ is identified as an intermediate filament-associated protein that aggregates keratin intermediate filaments in mammalian epidermis, which, in turn, promotes epidermal barrier formation [44]. Thus, it was suggested that mutations in FLG might disturb the physical barrier, increasing the permeability of environmental carcinogens resulting in somatic mutations and tumorigenesis at an early age [41].

There is more evidence to support that EOBC somatic mutation profile is different from that of late-onset breast cancer. In a study that examined young Latin American breast cancer patients, TP53 mutations showed an unexpected pattern of mutations not common in breast cancer, where $27 \%$ of the mutations were single-base substitutiontransversion mutations G:C > T:A compared to other young and old breast cancer cohorts used for comparison (METABRIC, TCGA, and International Agency for Research on Cancer IARC) [45]. This proportion and pattern of mutations were described earlier in lung cancer patients and attributed to exposure to exogenous agent, polycyclic aromatic hydrocarbons (PAHs) [46]. Surprisingly, studies in the field of occupational and environmental medicine provided evidence of increased risk of breast cancer related to exposure to PAHs, mainly among cases with family history and premenopausal status [47,48]. This association needs further investigation to understand why carcinogenic PAHs develop EOBC more than late-onset breast cancer.

To summarize, although the cut-off age of EOBC differs from one study to another, as varying public databases were also used to generate these results, we have realized that most studies examining somatic mutations share the same mutational theme, that is, the higher mutational frequency in genes encodes adhesion and extracellular matrix molecules. This is consistent with EOBC infiltrating and metastatic behaviors, considering the important role of the extracellular matrix (ECM) in providing structural and biochemical support for cancer stem cells that in turn induces cancer stemness [49]. Inhibitors that target ECM can, therefore, be an effective choice in the treatment of EOBC patients. However, more research in this area is needed. Additionally, genetic panel testing of most frequent mutations (TP53, CDH1, PIK3CA, GATA3, and CTNNB1) can assist in EOBC management and prediction of tumor prognosis. The ethnicity of the patient, however, should also be taken into consideration, as it is apparent that the incidence of mutations varies between different ethnicities.

\section{Chromosome Copy Number Variants (CNVs)}

Chromosome copy number variant $(\mathrm{CNV})$ is a form of genetic structural variation, defined by any increase or decrease in the number of DNA segments that measure around one kilobase (1000 base pairs) or more [50]. Azim et al. detected one chromosome copy number variant to be significantly associated with EOBC ( $\leq 45$ years) (deletion in chr6q27) in comparison to late-onset breast cancer ( $\geq 70$ years) [34]. Investigating the significance of genes located in chromosome 6, it appears that chromosome 6 long arm holds genes that reflects tumorigenic and metastatic features in many cancer cell lines [51,52], in particular, growth-suppressing genes in breast cancer cells. The significance of allele loss in chromosome 6 to breast cancer is due to the localization of estrogen receptor in 6q23-6q25 regions; loss in these regions may give rise to less differentiated and aggressive breast tumors [52].

Another group of researchers using Genomic Identification of Significant Targets (GISTIC) tool recognized two regions of amplification (6p23 and 7p21.1) and three regions of deletion (19q13.32, 22q12.3, and 22q13.31) in estrogen receptor-positive breast cancer young age patients ( $\leq 45$ years) compared to their older counterparts ( $\geq 55$ years) [31]. To emphasize the impact of those chromosomal aberrations on breast cancer, loss and gain in chromosome 7 short arm were reported in primary breast cancer and early-stage lung adenocarcinoma [53,54]; genes present within chromosome 7 were suggested to play an important role in breast cancer tumorigenesis [53]. Loss of heterozygosity (LOH) in chromo- 
some 19q13.3 was detected with higher frequency in secondary glioblastomas compared to primary glioblastomas, providing evidence that $\mathrm{LOH}$ in 19q13.3 may contribute to disease progression. An additional point to note is that chromosome 19q13.3 region contains $B A X$ gene [55], which induces cell apoptosis. Disturbed apoptotic pathways resulted in cancer growth and resistance to anti-cancer therapy. Low expression of $B A X$ gene was reported in all breast cancer subtypes [56,57]. Lastly, loss of chromosome 22 long arm is common in breast cancer. Castells et al. reported loss in chromosome 22q in more than half of invasive ductal carcinoma cases $(15 / 28)$ and $75 \%$ of lobular carcinoma cases (3/4); conversely, none of the ductal carcinomas in situ showed loss in any 22q loci. Thus, it was assumed that the long arm of chromosome 22 contains genes that might have contributed to advance-stage tumor progression [58].

Meanwhile, Ghaffari et al. reported a change in copy number variant in BIRC5 gene among EOBC patients, out of 40 breast cancer tissue samples tested, 7 samples showed amplification in BIRC5, of which 5 were from patients younger than 40 years at diagnosis [59]. BIRC5 gene contributes to apoptosis modulation and interleukin-11 signaling pathway. Thus, it may play an important role in cell cycle regulation and various cell cycle checkpoints [60]. A previous study reported correlation between BIRC5 expression and increased survival time to relapse or death [61].

To conclude, EOBC copy number variant-based studies presented CNVs contributed to EOBC tumorigenesis (6q27,6p32, and 7p21.1), advance-stage tumor progression (22q12.3 and 22q13.31), disease progression (19q13.32), and prognosis (copy number variant in BIRC5 gene). However, further studies that correlate CNV profile with gene and protein expression profile are needed to validate these findings.

\section{Single Nucleotide Polymorphism}

Single nucleotide polymorphism (SNP) is a form of genetic variation, which ultimately may affect protein structure and function [62]. An interesting meta-analysis study that examined 6042 breast cancer patients, including 2315 aged $\leq 40$ years at diagnosis, identified 2 SNPs associated with disease progression in EOBC ( $\leq 40$ years). Both SNP rs715212 $\left(\right.$ P meta $\left.=3.54 \times 10^{-5}\right)$ and $r$ r10963755 $\left(\mathrm{P}\right.$ meta $\left.=3.91 \times 10^{-4}\right)$ were found in the ADAMTSL1 gene. Further expression quantitative trait locus analysis supports the hypothesis that rs715212 may influence Amphiregulin (AREG) expression [7]. AREG gene, which shows higher expression in EOBC [31], has been determined to regulate T-regulatory cells creating an immune-suppressed tumor environment [63]; most importantly, it contributes to resistance to chemotherapy [64].

Meanwhile, a comparable study that examined only Caucasian women detected 12 SNPs associated with EOBC. All these 12 SNPs were near or within the MAP3K1 gene. The SNPs with lowest $p$-value were rs2229882 and rs889312. However, after multiple comparisons, most of the SNPs were also detected in late-onset breast cancer, which made the researchers suggest that late- and $\mathrm{EOBC}$ may share the same genetic profile [65]. Unexpectedly, a subsequent study found that SNP, MAP3K1 rs889312 (C/C allele) was significantly associated with poor disease-free survival, distant disease-free survival, and overall survival in hormone receptor-positive breast cancer patients, predominantly in premenopausal patients [66].

Tunisian EOBC patients ( $<40$ years) exhibited genetic polymorphism of major histocompatibility complex class I-related chain A (MICA) in comparison to their older counterparts. MICA is a glycoprotein that has been determined to play an important role in the modulation of host immune response, suggesting that it may mediate cell viability by letting tumor cell evade host immune system [67].

Considering the above findings, SNP studies highlighted the significant contributions of different SNPs to EOBC tumorigenesis, progression, resistance to chemotherapy, and poor prognosis. However, most of those studies were limited to homogenous populations. Thus, larger sample size studies with heterogeneous population will be needed to validate and generalize these findings. 


\section{Differential Gene Expression Profile}

In 2008, Andres and her colleagues found that gene occurrence in breast cancer patients appears in an age-related manner; further, they determined that there are more than 367 gene sets differentially expressed in young patients ( $\leq 45$ years) in comparison to older patients ( $\geq 65$ years). However, in 2011, the same group of researchers reanalyzed the exact data by building a statistical model to demonstrate differentially expressed genes between the two age groups and to exclude any cofounders. The model yielded 693 genes, but after clinicopathological correlation, gene expression differences diminished to 0 [68]. In contrast, a literature-based study revealed that breast cancer in young women ( $\leq 40$ years) was differentially enriched with gene sets representing luminal progenitor cells, immature mammary stem cells, and high levels of RANKL, c-kit, and BRCA1 mutations [69]. These controversial findings challenged more researchers to further investigate in this area.

Liao et al. reported 178 genes differentially expressed in young age estrogen receptorpositive breast cancer patients ( $\leq 45$ years) compared to their older counterparts ( $\geq 55$ years). In young age patients, significant genes were upregulated such as AREG, TFPI2, AMPH, DBX2, RP5-1054A22.3, and KLK5, while ESR1, CYP4Z1, RANBP3L, FOXD2, and PEX3 were downregulated [31]. Yau C. et al. have also reported 24 genes highly expressed in estrogen receptor-positive sporadic breast cancer young age patients ( $\leq 45$ years) (AREG, PRSS, GREB, PTHLH, HPGD, STK6, FGFR1, and DLG7) compared to old age patients ( $\geq 70$ years) [70]. Implications of up- and downregulated genes to breast cancer are summarized in Table 2.

Analyses of two microarray datasets (GSE109169-GSE89116) have revealed differential expression of PPARG and SQLE genes in EOBC tumor tissues ( $<40$ years) compared to normal breast tissues. PPARG was downregulated in EOBC tumor tissue [87]. It was established that the level of Peroxisome proliferator-activated receptor $\gamma$ (PPARG) is related to breast cancer patient prognosis. Low level of expression of PPARG was observed in patients with local recurrence and in patients who died of breast cancer [88]. Meanwhile, $S Q L E$, which encodes squalene epoxidase a rate-limiting enzyme in sterol biosynthesis and a significant therapeutic target for breast cancer, was upregulated in EOBC tumor tissue [87]. SQLE expression, which was associated with poor prognosis, was found to be highly expressed among black women compared to white women in a previous study [89]. Taking into account that black women have twice the incidence of EOBC [10], and by considering that this study used data generated from two Asian population (Indian and Taiwanese), we assumed that SQLE expression in breast cancer is related to EOBC more than patient ethnicity.

In conclusion, it can be noted that most EOBC gene expression studies include only estrogen receptor-positive breast cancer cases, as there is lacking difference in gene expression profile of estrogen receptor-negative cases among different age groups. However, the findings of those studies are valuable and serves as guidance for further investigation. 
Table 2. Implications of the upregulated and downregulated genes in EOBC to breast cancer.

\begin{tabular}{|c|c|c|c|}
\hline GENE & Gene Status in EOBC & Gene Role & References \\
\hline AREG & $\begin{array}{l}\text { Upregulated in young age } \\
\text { estrogen receptor-positive } \\
\text { breast cancer patients } \\
\text { ( } \leq 45 \text { years) }\end{array}$ & $\begin{array}{l}\text { Amphiregulin (AREG) is a growth factor essential for the } \\
\text { development of normal mammary gland and mammary stem cell } \\
\text { differentiation as well as estrogen receptor-positive breast tumour. } \\
\text { AREG was reported to engage in regulating proliferation and } \\
\text { migration of HER2-positive breast cancer cells. } \\
\text { In vitro study showed that AREG knockdown may slow down breast } \\
\text { cancer cell growth but will not completely inhibit it. However, it will } \\
\text { affect breast cancer cell invasion dramatically. }\end{array}$ & {$[63,71-73]$} \\
\hline TFPI2 & $\begin{array}{l}\text { Upregulated in young age } \\
\text { estrogen receptor-positive } \\
\text { breast cancer patients } \\
\text { ( } \leq 45 \text { years) }\end{array}$ & $\begin{array}{l}\text { Human tissue factor pathway inhibitor-2 (TFPI-2) encodes for a wide } \\
\text { spectrum of serine proteinase inhibitors which in turn inversely } \\
\text { regulates the extracellular matrix degradation, a key step toward } \\
\text { tumor invasion and metastasis. TFPI2 was found to be } \\
\text { hypermethylated and consequently downregulated in highly invasive } \\
\text { breast cancer cell lines. }\end{array}$ & {$[74,75]$} \\
\hline$D B X 2$ & $\begin{array}{l}\text { Upregulated in young age } \\
\text { estrogen receptor-positive } \\
\text { breast cancer patients } \\
\text { ( } \leq 45 \text { years) }\end{array}$ & $\begin{array}{l}\text { Developing brain homeobox } 2 \text { (DBX2) plays vital role in cell } \\
\text { differentiation and is usually upregulated in cancer tissues. DBX2 was } \\
\text { significantly upregulated in hepatocellular carcinoma tissues and } \\
\text { found to play major roles in the proliferation and metastasis of } \\
\text { hepatocellular carcinoma cells through Shh pathway. }\end{array}$ & [76] \\
\hline KLK5 & $\begin{array}{l}\text { Upregulated in young age } \\
\text { oestrogen receptor-positive } \\
\text { breast cancer patients } \\
\text { ( } \leq 45 \text { years })\end{array}$ & $\begin{array}{l}\text { Overexpression of kallikrein gene was significantly associated with } \\
\text { premenopausal, lymph node-positive, and estrogen receptor-negative } \\
\text { breast tumors. It was also associated with reduced breast cancer } \\
\text { patients, disease-free survival, and overall survival. } \\
\text { Finally, KLK5 was considered unfavourable independent prognostic } \\
\text { marker for breast cancer. }\end{array}$ & [77] \\
\hline ESR1 & $\begin{array}{l}\text { Downregulated in young age } \\
\text { estrogen receptor-positive } \\
\text { breast cancer patients } \\
\text { ( } \leq 45 \text { years) }\end{array}$ & $\begin{array}{l}\text { Downregulation of estrogen receptor has been considered a } \\
\text { prognostic factor for local recurrence and distant metastasis. Lower } \\
\text { expression of ESR1 was associated with higher tumor grade. }\end{array}$ & [78] \\
\hline CYP4Z1 & $\begin{array}{l}\text { Downregulated in young age } \\
\text { estrogen receptor-positive } \\
\text { breast cancer patients } \\
\text { ( } \leq 45 \text { years) }\end{array}$ & $\begin{array}{l}\text { Cytochrome P450 (CYP) } 4 Z 1 \text { frequently overexpressed in breast } \\
\text { cancer tissue and correlates with high tumor grade and poor } \\
\text { prognosis as CYP } 4 Z 1 \text { has been determined to be involved in tumor } \\
\text { angiogenesis and tumor cell proliferation. }\end{array}$ & [79] \\
\hline FOXD2 & $\begin{array}{l}\text { Downregulated in young age } \\
\text { estrogen receptor-positive } \\
\text { breast cancer patients } \\
\text { ( } \leq 45 \text { years) }\end{array}$ & $\begin{array}{l}\text { Upregulation of FOXD2-AS1 was associated with poor prognosis } \\
\text { among breast cancer patients, as it has been found to be involved in } \\
\text { breast cancer cell proliferation, migration, and invasion ability. }\end{array}$ & {$[80]$} \\
\hline GREB & $\begin{array}{l}\text { Highly expressed in estrogen } \\
\text { receptor-positive breast cancer } \\
\text { young age patients }\end{array}$ & $\begin{array}{l}\text { Previous literature suggests that growth regulation by estrogen in } \\
\text { breast cancer }(G R E B) \text { is involved in the estrogen-induced growth of } \\
\text { breast cancer. } \\
\text { It is also considered a clinical marker for response to } \\
\text { endocrine therapy. }\end{array}$ & [81] \\
\hline PTHLH & $\begin{array}{l}\text { Highly expressed in estrogen } \\
\text { receptor-positive breast cancer } \\
\text { young age patients }\end{array}$ & $\begin{array}{l}\text { Elevated parathyroid hormone-like hormone }(P T H L H) \text { production has } \\
\text { been found to be associated with metastasis of breast cancer to } \\
\text { the bone. }\end{array}$ & [82] \\
\hline$H P G D$ & $\begin{array}{l}\text { Highly expressed in estrogen } \\
\text { receptor-positive breast cancer } \\
\text { young age patients }\end{array}$ & $\begin{array}{l}\text { Hydroxyprostaglandin dehydrogenase (HPGD) has been determined } \\
\text { to be correlated with activity of estrogen pathway and possesses } \\
\text { tumor suppressive activity. SNP rs } 8752 \text { in miR- } 485-5 \text { p binding site in } \\
\text { HPGD gene was found to be associated with high risk of breast cancer. }\end{array}$ & [83] \\
\hline STK6 & $\begin{array}{l}\text { Highly expressed in estrogen } \\
\text { receptor-positive sporadic } \\
\text { breast cancer young } \\
\text { age patients }\end{array}$ & $\begin{array}{l}\text { Aurora kinase A is involved in the proliferation, mitotic checkpoint } \\
\text { control, and cell growth in breast cancer basal subtype. }\end{array}$ & {$[84]$} \\
\hline FGFR1 & $\begin{array}{l}\text { Highly expressed in estrogen } \\
\text { receptor-positive sporadic } \\
\text { breast cancer young } \\
\text { age patients }\end{array}$ & $\begin{array}{l}\text { Fibroblast growth factor receptor } 1 \text { is associated with poor prognosis } \\
\text { in luminal subtype breast cancer patients; also, it was found to induce } \\
\text { endocrine therapy resistance. }\end{array}$ & [85] \\
\hline DLG7 & $\begin{array}{l}\text { Highly expressed in estrogen } \\
\text { receptor-positive sporadic } \\
\text { breast cancer young } \\
\text { age patients }\end{array}$ & $\begin{array}{l}\text { Disc large homolog } 7 \text { had critical role throughout spindle assembly } \\
\text { which is important for genomic stability. Upregulation of } D L G 7 \text { is } \\
\text { associated with worse overall survival in distinct subtypes of } \\
\text { colorectal cancer patients. }\end{array}$ & [86] \\
\hline
\end{tabular}




\section{MicroRNAs}

MicroRNAs (miRNAs) are small RNA molecules that regulate gene expression posttranscriptionally. MicroRNAs are often considered new biomarkers utilized in the prediction of various biological processes, such as cell differentiation, cell cycle regulation, development, and apoptosis. Any disruption in the microRNA expression may result in a change in the gene expression profile of the cell and, consequently, in initiation and progression of syndromes, including cancer [90].

It is possible to discriminate breast cancer arising in young women from that in older women using microRNA profile. As per the findings of Peña-Chilet et al., it was determined that normal breast tissue and breast cancer tissue from older women ( $\geq 65$ years) share almost similar microRNA profile, contrary to the profile obtained from younger women below the age of 35 years [91].

Several microRNAs were implicated in the aggressive phenotype seen in EOBC; eight microRNAs were differentially expressed in estrogen receptor-positive breast tumors from young age patients ( 35 years or less) compared to tumors from older patients (50-65 years). Seven of these microRNAs were upregulated (miR-9, miR-210, miR-106a, miR-106b, miR-18b, miR-33b, and miR-518a-3p), and only one was downregulated (miR372). The expression level of most of those deregulated microRNAs was associated with higher tumor size and TNM stage ( $p$-value $<0.05)$ [92].

Breast tumors from very young age patients (35 years or less) showed differential expression of six microRNAs (hsa-miR-1228*, hsa-miR-3196, hsa-miR-1275, hsa-miR-1207$5 p$, hsa-miR-92b and hsa-miR-139-5p) compared to tumors from patients above 65 years of age. The deregulated microRNAs were significant for pathways relevant to apoptosis, cell motility, proliferation, mitotic regulatory processes, phosphatidylinositol 3-kinase (PI3K) and Insulin-like growth factor-1 receptor (IGFR) transduction [91]; all those pathways grant for the tumor high metastatic capacity by inducing progression and invasion.

Three microRNA expressions (miR-1285-5p, miR-183-5p, and miR-194-5p) were determined to be correlated with overall survival of very young breast cancer patients ( $<35$ years) who had poor prognosis (recurrence within 5 years of primary diagnosis) [4]. Differentially expressed miRNAs serve as a promising area for further exploration. Implications of all deregulated microRNAs in EOBC mentioned in this section is described in Table 3.

Table 3. Implication of EOBC deregulated microRNAs to breast cancer.

\begin{tabular}{cll}
\hline MicroRNA & \multicolumn{1}{c}{ Status in EOBC } & \multicolumn{1}{c}{ Implication to Breast Cancer } \\
\hline miR-9 & $\begin{array}{l}\text { Upregulated in estrogen } \\
\text { receptor-positive tumors } \\
\text { in patients with } \\
\text { age } \leq 35 \text { years. }\end{array}$ & $\begin{array}{l}\text { Previous literature suggests direct involvement of miRNA-9 in } \\
\text { breast cancer metastasis, due to the different levels of } \\
\text { expression through different stages of breast cancer. MTHFD2 is } \\
\text { one of the genes targeted by miR-9, which plays a role in cell } \\
\text { viability and anti-apoptotic activity. }\end{array}$ \\
\hline [93,94] \\
miR-210 & $\begin{array}{l}\text { Upregulated in estrogen } \\
\text { receptor-positive tumors } \\
\text { in patients with } \\
\text { age } \leq 35 \text { years. }\end{array}$ & $\begin{array}{l}\text { A known hypoxia-regulated microRNA, which is upregulated } \\
\text { in normal and transformed hypoxic cells, miR-210 has been } \\
\text { found to be vital during tumor initiation and growth by } \\
\text { reducing mitochondrial respiration in the hypoxic } \\
\text { microenvironment. }\end{array}$ \\
\hline miR-106a & $\begin{array}{l}\text { Upregulated in estrogen } \\
\text { receptor-positive tumors } \\
\text { in patients with } \\
\text { age } \leq 35 \text { years. }\end{array}$ & $\begin{array}{l}\text { The upregulation of miR-106a has been proven to induce breast } \\
\text { cancer cell proliferation, colony formation, migration, and } \\
\text { invasion in vitro. Moreover, miR-106a upregulation } \\
\text { significantly reduces breast cancer cell apoptosis and sensitivity } \\
\text { to cisplatin. }\end{array}$ \\
\hline [97]
\end{tabular}


Table 3. Cont.

\begin{tabular}{|c|c|c|c|}
\hline MicroRNA & Status in EOBC & Implication to Breast Cancer & Reference \\
\hline miR-18b & $\begin{array}{l}\text { Upregulated in estrogen } \\
\text { receptor-positive tumors } \\
\text { in patients with } \\
\text { age } \leq 35 \text { years. }\end{array}$ & $\begin{array}{l}\text { miR- } 18 \mathrm{~b} \text { is involved in the modulation of breast cancer cell } \\
\text { migration and metastasis in vitro. }\end{array}$ & [99] \\
\hline miR-33b & $\begin{array}{l}\text { Upregulated in estrogen } \\
\text { receptor-positive tumors } \\
\text { in patients with } \\
\text { age } \leq 35 \text { years. }\end{array}$ & $\begin{array}{l}\text { miR-33b is frequently downregulated in breast cancer tissue in } \\
\text { comparison to normal adjacent tissue. A previous study } \\
\text { recognized miR-33b as a negative regulator for metastasis and } \\
\text { breast cancer cell stemness. }\end{array}$ & {$[100]$} \\
\hline $\operatorname{miR}-518 a-3 p$ & $\begin{array}{l}\text { Upregulated in estrogen } \\
\text { receptor-positive tumors } \\
\text { in patients with } \\
\text { age } \leq 35 \text { years. }\end{array}$ & $\begin{array}{l}\text { Expression of miR-518a-3p was associated with cell } \\
\text { proliferation in several malignancies. miR-518a-3p expression } \\
\text { was positively correlated with overall survival in } \\
\text { triple-negative breast cancer patients. }\end{array}$ & {$[101]$} \\
\hline $\operatorname{miR}-372$ & $\begin{array}{l}\text { Downregulated in } \\
\text { estrogen receptor-positive } \\
\text { tumors in patients with } \\
\text { age } \leq 35 \text { years. }\end{array}$ & $\begin{array}{l}\text { Frequently overexpressed in breast tumor tissue. } \\
\text { Downregulation of miR-372 significantly inhibited cell } \\
\text { proliferation and induced apoptosis of breast cancer cells. }\end{array}$ & {$[102]$} \\
\hline hsa-miR-1228* & $\begin{array}{l}\text { Deregulated in young age } \\
\text { breast cancer patients } \\
(\leq 35 \text { years })\end{array}$ & $\begin{array}{l}\text { miR-1228 plays a vital role in the regulation of cell proliferation } \\
\text { and metastasis in cancer cells. }\end{array}$ & {$[103,104]$} \\
\hline hsa-miR-3196 & $\begin{array}{l}\text { Deregulated in young age } \\
\text { breast cancer patients } \\
\text { ( } \leq 35 \text { years). }\end{array}$ & $\begin{array}{l}\text { Few studies elucidate the role of hsa-miR-3196 in cancer } \\
\text { progression. However, miR-3196 was downregulated in basal } \\
\text { cell carcinoma compared with non-lesional skin. }\end{array}$ & {$[105]$} \\
\hline hsa-miR-1275 & $\begin{array}{l}\text { Deregulated in young age } \\
\text { breast cancer patients } \\
\text { ( } \leq 35 \text { years). }\end{array}$ & $\begin{array}{l}\text { Upregulated miR-1275 has been reported to induce p53 } \\
\text { signaling pathway via regulating serpin family E member } \\
1 \text { (SERPINE1) (which is member in P53 signalling pathway and } \\
\text { is also a known protein involved in cell adhesion) that } \\
\text { suppresses tumour cells proliferation, invasion, and migration } \\
\text { while at the same time, promoting cell apoptosis. (In vitro and } \\
\text { in vivo study in glioma). Another role for hsa-miR-1275 is to } \\
\text { inhibit adipogenesis in obesity. }\end{array}$ & [106-108] \\
\hline hsa-miR-1207-5p & $\begin{array}{l}\text { Deregulated in young age } \\
\text { breast cancer patients } \\
\text { ( } \leq 35 \text { years). }\end{array}$ & $\begin{array}{l}\text { Low expression of } 1207-5 p \text { targeted mRNA was reported to } \\
\text { regulate tumor protein p53, transforming growth factor } \beta \\
\text { (TGF-b) and insulin signaling pathways in metabolic } \\
\text { syndrome patients. } \\
\text { P53, TGF-b, and insulin signaling pathways are implicated in } \\
\text { the initiation, progression, and metastasis of breast cancer. }\end{array}$ & {$[109]$} \\
\hline hsa-miR-92b & $\begin{array}{l}\text { Deregulated in young age } \\
\text { breast cancer patients } \\
\text { ( } \leq 35 \text { years })\end{array}$ & $\begin{array}{l}\text { Has-miR-92b expression inhibits breast cancer cell viability, } \\
\text { invasion, migration, and control autophagy through histone } \\
\text { methyltransferase enhancer of zeste homolog } 2 \text { (EZH2) in vitro. }\end{array}$ & {$[110]$} \\
\hline hsa-miR-139-5p & $\begin{array}{l}\text { Deregulated in young age } \\
\text { breast cancer patients } \\
\text { ( } \leq 35 \text { years). }\end{array}$ & $\begin{array}{l}\text { hsa-miR-139-5p expression induces apoptosis and arrests cell } \\
\text { cycle in S phase. Furthermore, it inhibits viability, migration, } \\
\text { and invasion in breast cancer cells via targeting Notch } \\
\text { signaling pathway. }\end{array}$ & {$[111]$} \\
\hline miR-1285-5p & $\begin{array}{l}\text { Correlated with overall } \\
\text { survival in young age } \\
\text { breast cancer patients } \\
\text { ( } \leq 35 \text { years). }\end{array}$ & $\begin{array}{l}\text { miR-1285-5p suppresses breast cancer cell proliferation activity } \\
\text { via upregulation of targeted gene transmembrane protein } 194 \mathrm{~A} \\
\text { (TMEM194A). }\end{array}$ & {$[112]$} \\
\hline $\operatorname{miR}-183-5 p$ & $\begin{array}{l}\text { Correlated with overall } \\
\text { survival in young age } \\
\text { breast cancer patients } \\
\text { ( } \leq 35 \text { years). }\end{array}$ & $\begin{array}{l}\text { miR-183-5p have oncomiR effects on breast cancer cells. } \\
\text { Overexpression of miR-183-5p can significantly induce breast } \\
\text { cancer cell proliferation and inhibit apoptosis in vitro. }\end{array}$ & {$[113]$} \\
\hline miR-194-5p & $\begin{array}{l}\text { Correlated with overall } \\
\text { survival in young age } \\
\text { breast cancer patients } \\
\text { ( } \leq 35 \text { years). }\end{array}$ & $\begin{array}{l}\text { miR-194-5p were found to be upregulated in breast cancer } \\
\text { tissue. } \\
\text { Knockdown of miR-194-5p in breast cancer cell resulted in } \\
\text { inhibition of cell proliferation, migration, and invasion via } \\
\text { expression of SOX17 and regulation of the canonical Wnt } \\
\text { (Wnt/ } \beta \text {-catenin) signaling pathway. }\end{array}$ & {$[114]$} \\
\hline
\end{tabular}




\section{DNA Methylation Profile}

DNA methylation is one of the epigenetic machineries deemed crucial for the normal development and maintenance of tissue-specific gene expression [115]. EOBC has been often characterized by having hypomethylated DNA profile in comparison to late-onset breast cancer, where hypomethylation was determined in $69 \%$ of significant $\mathrm{CpG}$ sites. Pathways affected by methylation in EOBC include those related to the neuronal system, extracellular matrix modulation, immune system, DNA repair, Notch/Notch1 signaling, and vesicular trafficking. DNA methylation in EOBC resulted in significant upregulation of $H D A C 5$ which proved to promote tamoxifen resistance through cancer stem cell-related transcription factor SOX9 deacetylation, as well as significant downregulation of EHF that involves in epithelial mesenchymal transition inducing metastasis [116].

By using TCGA methylation data, 373 genes were hypomethylated, whereas 457 genes were hypermethylated in estrogen receptor-positive young age breast cancer patients ( $\leq 45$ years) compared to their older counterparts ( $\geq 65$ years). The significant hypermethylated genes were ESR1, MAT2B, CTSS, DDR2, and GALNTL2 [31]. Methionine Adenosyltransferase 2B (MAT2B) has been determined to be involved in cell metabolism including proliferation and apoptosis; further, higher expression of $M A T 2 B$ was correlated with good prognosis in estrogen receptor-positive breast cancer patients [117]. Meanwhile, CTSS gene has been identified to encode Cathepsin S protein which plays a significant role in genomic stability through abolishing BRCA1 activity; further, CTTS knockdown was found to be associated with suppression of tumor metastasis in triple-negative breast cancer cell [118]. Overall, DNA methylation events appears to play vital role in EOBC aggressive characteristics.

\section{Differentially Expressed Proteins}

Several proteins showed significant differential expression in young age patients (less than 35 years) compared to older age patients (between 50 and 65 years). Bcl-2-like protein 1 (BCL2L1), Poly [ADP-ribose] polymerase 1 (PRP1), and RAF proto-oncogene serine (RAF1) were determined to be overexpressed, whereas Estrogen receptor (ESR1), Eukaryotic translation initiation factor 4E (EIF4E), Signal transducer and activator of transcription 5A (STAT5A), and Ribosomal protein S6 kinase alpha-1 (RPS6KA1) were underexpressed. The pattern of expression of the deregulated proteins was linked to the clinical parameters of EOBC. Higher expression of PRP1 and lower expression of RPS6KA1 were associated with positive lymph nodes status, whereas overexpression of RAF1 and underexpression of STAT5A were correlated with high TNM stage [92].

By utilizing immunohistochemical staining, Hasoda et al. recognized significant higher expression level of Receptor activator of nuclear factor kappa-B ligand (RANKL), GATA3, Progesterone receptor (PgR), and Trefoil factor 1 (TFF1) in estrogen-positive and HER-2-negative breast cancer patients (age range between 27 and 56 years) [119]. Table 4. illustrates the functions of over- and underexpressed proteins in breast cancer. 
Table 4. The role of EOBC over- and underexpressed proteins in breast cancer.

\begin{tabular}{|c|c|c|c|}
\hline Protein & Expression Status in EOBC & Role of Protein & Reference \\
\hline BCL2L1 & Overexpressed & $\begin{array}{l}\text { Belongs to the BCL2 protein family that act as } \\
\text { anti-apoptotic regulators that are involved in a } \\
\text { wide variety of cellular activities. } \\
\text { Tamoxifen treatments induce apoptosis by } \\
\text { reducing BCL2 level in breast cancer. }\end{array}$ & $\begin{array}{l}\text { https: / / www.ncbi.nlm. } \\
\text { nih.gov/gene/598 } \\
\text { (accessed on } 4 \text { March } \\
\text { 2021), [120] }\end{array}$ \\
\hline PARP1 & Overexpressed & $\begin{array}{l}\text { Co-expressed with other DNA repair proteins } \\
\text { suggesting that it may have a role in DNA repair } \\
\text { process. PARP1 expression was determined to be } \\
\text { related to younger age, larger tumor size, and } \\
\text { higher tumor grade in breast cancer. }\end{array}$ & [121] \\
\hline RAF1 & Overexpressed & $\begin{array}{l}\text { Raf- } 1 \text { and Bcl- } 2 \text { were found to induce different } \\
\text { and overlapping pathways that contributed to } \\
\text { drug resistance. Mutations like amplification of } \\
\text { c-erbB-2 oncogene, which is frequent in young } \\
\text { age breast cancer patients, may lead to activating } \\
\text { Raf, resulting in resistance to certain } \\
\text { chemotherapeutic drugs. }\end{array}$ & [122] \\
\hline ESR1 & Low expression & $\begin{array}{l}\text { ESR1 lower expression is a predictive factor for } \\
\text { endocrine therapy resistance. }\end{array}$ & [123] \\
\hline EIF4E & Low expression & $\begin{array}{l}\text { eIF4E expression was positively associated with } \\
\text { breast tumor grade. }\end{array}$ & [124] \\
\hline STAT5A & Low expression & $\begin{array}{l}\text { Low level of Stat5a expression was associated } \\
\text { with poor prognosis in node-negative breast } \\
\text { cancer tumours. }\end{array}$ & [125] \\
\hline RPS6KA1 & Low expression & $\begin{array}{l}\text { RPS6K encodes protein that contributes to the } \\
\text { control of cell growth and proliferation. }\end{array}$ & $\begin{array}{l}\text { https://www.ncbi.nlm. } \\
\text { nih.gov/gene/6194 } \\
\text { (accessed on } 4 \text { March 2021) }\end{array}$ \\
\hline TFF1 & $\begin{array}{l}\text { Highly expressed in oestrogen } \\
\text { receptor-positive and } \\
\text { HER-2-negative breast cancer } \\
\text { patients with age ( } 27-56 \text { years) }\end{array}$ & $\begin{array}{l}\text { Expression of TFF1 regulated by estrogen plays a } \\
\text { role in breast cell metastasis. Inhibition of TFF1 } \\
\text { may increase hormonal therapies' efficacy. }\end{array}$ & [126] \\
\hline RANKL & $\begin{array}{l}\text { Highly expressed in oestrogen } \\
\text { receptor-positive and } \\
\text { HER-2-negative breast cancer } \\
\text { patients with age ( } 27-56 \text { years) }\end{array}$ & $\begin{array}{l}\text { RANKL participates in mammary gland } \\
\text { development during pregnancy and is involved } \\
\text { in the initiation and progression of } \\
\text { progesterone-induced breast cancer. }\end{array}$ & [127] \\
\hline $\operatorname{PgR}$ & $\begin{array}{l}\text { Highly expressed in oestrogen } \\
\text { receptor-positive and } \\
\text { HER-2-negative breast cancer } \\
\text { patients with age ( } 27-56 \text { years) }\end{array}$ & $\begin{array}{l}\text { Progesterone receptor plays an important role in } \\
\text { breast cancer initiation and progression. } \\
\text { Additionally, progesterone receptor expression is } \\
\text { important in the prediction and prognosis of } \\
\text { breast cancer. }\end{array}$ & [128] \\
\hline
\end{tabular}

\section{Altered Pathways}

The proto-oncogene MYC signaling pathway has been found to be significantly expressed in EOBC ( $\leq 45$ years) compared to late-onset breast cancer ( $\geq 45$ years) [129]. MYC pathway deregulation has been determined to play a role in the development, progression, metastasis, and therapy resistance of breast cancer [130]. Expression of MYC pathway can vary among different molecular subtypes of breast cancer. However, it is often overexpressed in aggressive subtypes such as basal-like subtype [130]. Furthermore, as EOBC has been determined to be rich in basal-like subtype, it was expected that MYC signaling pathways show higher expression.

Integrin, laminin, and epidermal growth factor receptor signaling pathways were the most significant altered pathways in young age estrogen receptor-positive breast cancer 
patients ( $\leq 45$ years) compared to older age patients [31]. Integrin membrane proteins maintain cell adhesion to the extracellular matrix, and upon loss of integrin, the cells will undergo apoptosis. Thus, integrin expression then mediates cell survival and is one of the factors that prevent the tumor cells from undergoing drug-induced apoptosis. $\beta 1$ integrin was also reported to mediate pathways that drive resistance to HER2-targeted therapies [131,132]. Integrin plays an important role in the migration, proliferation, and death of breast cancer cells [133]. A crosstalk between P-cadherin and laminin receptor and $\alpha 6 \beta 4$ integrin signaling pathway was reported in stem cell and invasive properties of breast cancer cells [134]. On the other hand, epidermal growth factor receptor signaling pathway is implicated in tamoxifen resistance, through activation of downstream kinases, extracellular signal-regulated protein kinases 1 and 2 (ERK1/2), MAP kinase (MAPK) and protein kinase B (AKT) [135]. Thus, it is clear that EOBC exhibits differential expression of pathways related to HER2-targeted therapies and induced tamoxifen resistance. This may provide a clue for tumor recurrence and poor outcome observed in EOBC.

\section{Tumor Microenvironment}

Tumor microenvironment plays an important role in breast cancer tumorigenesis and progression. Targeting malignant and non-malignant components of tumor microenvironment may help in cancer management [136]. Researchers suggested that endocrine changes during the reproductive age and gestation play a critical role in altering breast microenvironment in young women, as if it predisposes the tissue for tumorigenesis [137]. Eight stromal genes were differentially expressed in breast tumors from very young patients ( 35 years or less) compared to tumors from older age patients (50-65 years) (UQCRQ, ALDH1A3, EGLN1, and IGF1 overexpressed, while FUT9, IDI2, PDHX, and CCL18 underexpressed) [92]. Table 5 provides a summary of the implications of EOBC-deregulated stromal genes in breast cancer. 
Table 5. Implications of EOBC-deregulated stromal genes in breast cancer.

\begin{tabular}{|c|c|c|c|}
\hline Stromal Gene & $\begin{array}{l}\text { Expression Status in } \\
\text { Early-Onset Breast Cancer }\end{array}$ & Role & Reference \\
\hline UQCRQ & Overexpressed & $\begin{array}{l}\text { UQCRC1 is frequently highly expressed in breast cancer } \\
\text { tissues. Expression of UQCRC1 was positively } \\
\text { correlated with cytochrome c-oxidase (COXII), } \\
\text { suggesting that it may play a role in cell apoptosis. }\end{array}$ & {$[138,139]$} \\
\hline$A L D H 1 A 3$ & Overexpressed & $\begin{array}{l}\text { Aldehyde dehydrogenase ( } A L D H 1 A 3) \text { has been found } \\
\text { to be positively correlated with breast cancer tumor } \\
\text { grade, stage, and metastasis. }\end{array}$ & [140] \\
\hline EGLN1 & Overexpressed & $\begin{array}{l}\text { EGIN1 (also called the oxygen sensor PHD2) is the main } \\
\text { prolyl hydroxylase that regulates hypoxia-inducible } \\
\text { factor and epidermal growth factor expression in breast } \\
\text { cancer. It has been established that breast cancer with } \\
\text { high epidermal growth factor level is more aggressive. }\end{array}$ & [141] \\
\hline IGF1 & Overexpressed & $\begin{array}{l}\text { In addition to being reported as a potent mitogen for } \\
\text { breast cancer cells, IGF1 and IGF2 promote proliferation } \\
\text { and inhibit apoptosis of breast cancer cells. Knockdown } \\
\text { of their expression results in tumor growth inhibition. }\end{array}$ & [142] \\
\hline FUT9 & Underexpressed & $\begin{array}{l}\text { Fucosylation is a type of glycosylation process that has } \\
\text { been detected excessively in several malignancies. } \\
\text { Overexpression of fucosylated antigens was associated } \\
\text { with proliferation, metastasis, epithelial mesenchymal } \\
\text { transition, and multi-drug resistance. }\end{array}$ & [143] \\
\hline PDHX & Underexpressed & $\begin{array}{l}\text { Reduction in pyruvate dehydrogenase protein } X \text { level in } \\
\text { cell has resulted in a decrease in mitochondrial } \\
\text { oxidation, increase in extracellular acidification, and } \\
\text { change in the level of pyruvate, lactate, and citrate. } \\
\text { Collectively, this resulted in increasing cell } \\
\text { proliferation ability. }\end{array}$ & [144] \\
\hline CCL18 & Underexpressed & $\begin{array}{l}\text { Chemokine (C-C motif) ligand } 18 \text { (CCL18) is mainly } \\
\text { produced by tumor-associated macrophages and is } \\
\text { associated with metastasis and poor prognosis in breast } \\
\text { cancer patients. }\end{array}$ & [145] \\
\hline
\end{tabular}

\section{TP53}

It is impossible to skip the role of TP53 when dealing with EOBC. Thus, in here, we have also mentioned a recent and interesting study that reported significant lower expression of growth-arrest-specific 7 isoform $b(G A S 7 b)$ in young age breast cancer patients ( $\leq 40$ years old) compared to their older counterparts. Importantly, it should be noted that in normal physiological condition, wildtype TP53 binds to GAS7b promoter, inducing GAS7b transcription. However, in EOBC, the high mutational load of TP53 affects the rate of GAS7b transcription; considering the role of GAS7b in regulating cell structure and cell migration, this aberrant transcription may contribute to metastasis events [146]. This study revealed that TP53 mutations may have more implications beyond what was reported earlier; thus, further research is needed.

\section{Conclusions}

Considering all the above evidence, it can be concluded that EOBC has a distinct biology; however, this distinction is more prominent among estrogen receptor-positive and sporadic breast cancer tumors. Further advanced research is needed in order to discover novel molecular markers associated exclusively with EOBC, which may help in customizing the therapy for this group of patients. Additionally, genes related to tumor microenvironment and extracellular matrix proteins, in addition to pathways affected by TP53 mutations, may be a promising area for future research. 
Author Contributions: Conceptualization, A.S., W.F.W.A.R., and T.A.D.A.-A.T.D.; writing-original draft preparation, A.S.; writing-review and editing, A.S., S.N.M.N., M.M.Y., and S.S.; supervision, W.F.W.A.R.; All authors have read and agreed to the published version of the manuscript.

Funding: This research was funded by Fundamental Research Grant Scheme (FRGS) by Ministry of Higher Education Malaysia (MOHE), grant number 203.PPSP.6171249.

Institutional Review Board Statement: Not applicable.

Informed Consent Statement: Not applicable.

Data Availability Statement: Not applicable.

Acknowledgments: We are grateful to the Ministry of Higher Education Malaysia for supporting us with FRGS grant to implement this work.

Conflicts of Interest: The authors declare no conflict of interest. The funders had no role in the design of the study; in the collection, in the writing of the manuscript, or in the decision to publish this review article.

Review Criteria: We have explored search engines such as PubMed, Google Scholar, and ResearchGate using the keywords as follows: breast cancer, young women, genetic background, differential gene expression, copy variant number, breast cancer pathways, breast cancer mutations, and EOBC. Good-quality articles published in English and Spanish language were included if the data were relevant and useful for our review.

\section{References}

1. Bray, F.; Ferlay, J.; Soerjomataram, I.; Siegel, R.L.; Torre, L.A.; Jemal, A. Global cancer statistics 2018: GLOBOCAN estimates of incidence and mortality worldwide for 36 cancers in 185 countries. CA Cancer J. Clin. 2018, 68, 394-424. [CrossRef] [PubMed]

2. Elbasheer, M.M.A.; Alkhidir, A.G.A.; Mohammed, S.M.A.; Abbas, A.A.H.; Mohamed, A.O.; Bereir, I.M.; Abdalazeez, H.R.; Noma, M. Spatial distribution of breast cancer in Sudan 2010-2016. PLoS ONE 2019, 14, e0211085. [CrossRef]

3. Sotiriou, C.; Pusztai, L. Gene-Expression Signatures in Breast Cancer. N. Engl. J. Med. 2009, 360, 790-800. [CrossRef] [PubMed]

4. Hironaka-Mitsuhashi, A.; Matsuzaki, J.; Takahashi, R.-U.; Yoshida, M.; Nezu, Y.; Yamamoto, Y.; Shiino, S.; Kinoshita, T.; Ushijima, T.; Hiraoka, N.; et al. A tissue microRNA signature that predicts the prognosis of breast cancer in young women. PLoS ONE 2017, 12, e0187638. [CrossRef] [PubMed]

5. Gómez-Flores-Ramos, L.; Álvarez-Gómez, R.M.; Villarreal-Garza, C.; Wegman-Ostrosky, T.; Mohar, A. Breast cancer genetics in young women: What do we know? Mutat. Res. Mutat. Res. 2017, 774, 33-45. [CrossRef]

6. Gabriel, C.; Domchek, S. Breast cancer in young women. Breast Cancer Res. 2010, 12, 212. [CrossRef]

7. Kadalayil, L.; Khan, S.; Nevanlinna, H.; Fasching, P.A.; Couch, F.J.; Hopper, J.L.; Liu, J.; Maishman, T.; Durcan, L.; Gerty, S.; et al. Germline variation in ADAMTSL1 is associated with prognosis following breast cancer treatment in young women. Nat. Commun. 2017, 8, 1632. [CrossRef]

8. Yıldırım, E.; Dalgıç, T.; Berberoğlu, U. Prognostic significance of young age in breast cancer. J. Surg. Oncol. 2000, 74, 267-272. [CrossRef]

9. Brandt, J.; Garne, J.P.; Tengrup, I.; Manjer, J. Age at diagnosis in relation to survival following breast cancer: A cohort study. World J. Surg. Oncol. 2015, 13, 33. [CrossRef] [PubMed]

10. Anders, C.K.; Johnson, R.; Litton, J.; Phillips, M.; Bleyer, A. Breast cancer before age 40 years. Semin. Oncol. 2009, 36, 237-249. [CrossRef] [PubMed]

11. Bleyer, A.; on behalf of the Biology and Clinical Trials Subgroups of the US National Cancer Institute Progress Review Group in Adolescent and Young Adult Oncology; Barr, B.D.; Hayes-Lattin, B.; Thomas, D.L.; Ellis, C.; Anderson, B. The distinctive biology of cancer in adolescents and young adults. Nat. Rev. Cancer 2008, 8, 288-298. [CrossRef]

12. Peppercorn, J.; Partridge, A.H. Breast Cancer in Young Women: A New Color or a Different Shade of Pink? J. Clin. Oncol. 2008, 26, 3303-3305. [CrossRef] [PubMed]

13. Beadle, B.M.; Woodward, W.A.; Buchholz, T.A. The impact of age on outcome in early-stage breast cancer. Semin. Radiat. Oncol. 2011, 21, 26-34. [CrossRef]

14. Dai, D.; Zhong, Y.; Wang, Z.; Yousafzai, N.A.; Jin, H.; Wang, X. The prognostic impact of age in different molecular subtypes of breast cancer: A population-based study. PeerJ 2019, 7, e7252. [CrossRef]

15. Kataoka, A.; Iwamoto, T.; Tokunaga, E.; Tomotaki, A.; Kumamaru, H.; Miyata, H.; Niikura, N.; Kawai, M.; Anan, K.; Hayashi, N.; et al. Young adult breast cancer patients have a poor prognosis independent of prognostic clinicopathological factors: A study from the Japanese Breast Cancer Registry. Breast Cancer Res. Treat. 2016, 160, 163-172. [CrossRef] [PubMed]

16. Chollet-Hinton, L.; Anders, C.K.; Tse, C.-K.; Bell, M.B.; Yang, Y.C.; Carey, L.A.; Olshan, A.F.; Troester, M.A. Breast cancer biologic and etiologic heterogeneity by young age and menopausal status in the Carolina Breast Cancer Study: A case-control study. Breast Cancer Res. 2016, 18, 79. [CrossRef] 
17. Clavel-Chapelon, F.; the E3N-EPIC Group. Differential effects of reproductive factors on the risk of pre- and postmenopausal breast cancer. Results from a large cohort of French women. Br. J. Cancer 2002, 86, 723-727. [CrossRef]

18. Saxena, S.; Chakraborty, A.; Kaushal, M.; Kotwal, S.; Bhatanager, D.; Mohil, R.S.; Chintamani, C.; Aggarwal, A.K.; Sharma, V.K.; Sharma, P.C.; et al. Contribution of germline BRCA1 and BRCA2sequence alterations to breast cancer in Northern India. BMC Med. Genet. 2006, 7, 75. [CrossRef]

19. Sundquist, M.; Thorstenson, S.; Brudin, L.; Wingren, S.; Nordenskjöld, B. Incidence and prognosis in early onset breast cancer. Breast 2002, 11, 30-35. [CrossRef]

20. Ellisen, L.W.; Haber, D.A. HEREDITARY BREAST CANCER. Annu. Rev. Med. 1998, 49, 425-436. [CrossRef]

21. De Silva, S.; Tennekoon, K.H.; Karunanayake, E.H. Overview of the genetic basis toward early detection of breast cancer. Breast Cancer Targets Ther. 2019, 11, 71-80. [CrossRef] [PubMed]

22. Apostolou, P.; Fostira, F. Hereditary Breast Cancer: The Era of New Susceptibility Genes. BioMed Res. Int. 2013, $2013,747318$. [CrossRef]

23. Fitzgerald, M.G.; Bean, J.M.; Hegde, S.R.; Unsal, H.; Macdonald, D.J.; Harkin, D.P.; Finkelstein, D.M.; Isselbacher, K.J.; Haber, D.A. Heterozygous ATM mutations do not contribute to early onset of breast cancer. Nat. Genet. 1997, 15, 307-310. [CrossRef]

24. Freedman, R.A.; Partridge, A.H. Management of breast cancer in very young women. Breast 2013, 22, S176-S179. [CrossRef]

25. Peto, J.; Collins, N.; Barfoot, R.; Seal, S.; Warren, W.; Rahman, N.; Easton, D.F.; Evans, C.; Deacon, J.; Stratton, M.R. Prevalence of BRCA1 and BRCA2 Gene Mutations in Patients With Early-Onset Breast Cancer. J. Natl. Cancer Inst. 1999, 91, 943-949. [CrossRef]

26. Musolino, A.; Bella, M.A.; Bortesi, B.; Michiara, M.; Naldi, N.; Zanelli, P.; Capelletti, M.; Pezzuolo, D.; Camisa, R.; Savi, M.; et al. BRCA mutations, molecular markers, and clinical variables in early-onset breast cancer: A population-based study. Breast 2007, 16, 280-292. [CrossRef]

27. Malone, K.E.; Daling, J.R.; Neal, C.; Suter, N.M.; O’Brien, C.; Cushing-Haugen, K.; Jonasdottir, T.J.; Thompson, J.D.; Ostrander, E.A. Frequency ofBRCA1/BRCA2 mutations in a population-based sample of young breast carcinoma cases. Cancer 2000, 88, 1393-1402. [CrossRef]

28. Rogoża-Janiszewska, E.; Malińska, K.; Cybulski, C.; Jakubowska, A.; Gronwald, J.; Huzarski, T.; Lener, M.; Górski, B.; Kluźniak, W.; Rudnicka, H.; et al. Prevalence of Recurrent Mutations Predisposing to Breast Cancer in Early-Onset Breast Cancer Patients from Poland. Cancers 2020, 12, 2321. [CrossRef]

29. Chen, L.; Fu, F.; Huang, M.; Lv, J.; Zhang, W.; Wang, C. The spectrum of BRCA1 and BRCA2 mutations and clinicopathological characteristics in Chinese women with early-onset breast cancer. Breast Cancer Res. Treat. 2020, 180, 759-766. [CrossRef] [PubMed]

30. Bryan, M.S.; Argos, M.; Andrulis, I.L.; Hopper, J.L.; Chang-Claude, J.; Malone, K.; John, E.M.; Gammon, M.D.; Daly, M.; Terry, M.B.; et al. Limited influence of germline genetic variation on all-cause mortality in women with early onset breast cancer: Evidence from gene-based tests, single-marker regression, and whole-genome prediction. Breast Cancer Res. Treat. 2017, 164, 707-717. [CrossRef]

31. Liao, S.; Hartmaier, R.J.; McGuire, K.P.; Puhalla, S.L.; Luthra, S.; Chandran, U.R.; Ma, T.; Bhargava, R.; Modugno, F.; Davidson, N.E.; et al. The molecular landscape of premenopausal breast cancer. Breast Cancer Res. 2015, 17, 104. [CrossRef]

32. Pharoah, P.D.; Guilford, P.; Caldas, C. Incidence of gastric cancer and breast cancer in CDH1 (E-cadherin) mutation carriers from hereditary diffuse gastric cancer families. Gastroenterology 2001, 121, 1348-1353. [CrossRef]

33. Liu, J.; Sun, X.; Qin, S.; Wang, H.; Du, N.; Li, Y.; Pang, Y.; Wang, C.; Xu, C.; Ren, H. CDH1 promoter methylation correlates with decreased gene expression and poor prognosis in patients with breast cancer. Oncol. Lett. 2016, 11, 2635-2643. [CrossRef] [PubMed]

34. Azim, H.A., Jr.; Nguyen, B.; Brohée, S.; Zoppoli, G.; Sotiriou, C. Genomic aberrations in young and elderly breast cancer patients. BMC Med. 2015, 13, 266. [CrossRef]

35. Mealey, N.E.; O'Sullivan, D.E.; Pader, J.; Ruan, Y.; Wang, E.; Quan, M.L.; Brenner, D.R. Mutational landscape differences between young-onset and older-onset breast cancer patients. BMC Cancer 2020, 20, 212. [CrossRef]

36. Asselin-Labat, M.-L.; Sutherland, K.D.; E Barker, H.; Thomas, R.G.; Shackleton, M.; Forrest, N.C.; Hartley, L.; Robb, L.; Grosveld, F.G.; Van Der Wees, J.; et al. Gata-3 is an essential regulator of mammary-gland morphogenesis and luminal-cell differentiation. Nat. Cell Biol. 2006, 9, 201-209. [CrossRef]

37. GATA Binding Protein 3 Gene-GeneCards Human Genome Database. Available online: https://www.genecards.org/cgi-bin/ carddisp.pl?gene (accessed on 4 March 2021).

38. Mehra, R.; Varambally, S.; Ding, L.; Shen, R.; Sabel, M.S.; Ghosh, D.; Chinnaiyan, A.M.; Kleer, C.G. Identification of GATA3 as a breast cancer prognostic marker by global gene expression meta-analysis. Cancer Res. 2005, 65, 11259-11264. [CrossRef] [PubMed]

39. Villarreal-Garza, C.; Ferrigno, A.S.; De La Garza-Ramos, C.; Barragan-Carrillo, R.; Lambertini, M.; Azim, H.A. Clinical utility of genomic signatures in young breast cancer patients: A systematic review. NPJ Breast Cancer 2020, 6, 46. [CrossRef]

40. CTNNB1 Gene-GeneCards Human Genome Database. Available online: https://www.genecards.org/cgi-bin/carddisp.pl? gene $=$ CTNNB1 (accessed on 4 March 2021).

41. Midha, M.K.; Huang, Y.-F.; Yang, H.-H.; Fan, T.-C.; Chang, N.-C.; Chen, T.-H.; Wang, Y.-T.; Kuo, W.-H.; Chang, K.-J.; Shen, C.-Y.; et al. Comprehensive Cohort Analysis of Mutational Spectrum in Early Onset Breast Cancer Patients. Cancers 2020, 12, 2089. [CrossRef] [PubMed]

42. Jonckheere, N.; Skrypek, N.; Van Seuningen, I. Mucins and tumor resistance to chemotherapeutic drugs. Biochim. Biophys. Acta (BBA)-Rev. Cancer 2014, 1846, 142-151. [CrossRef] [PubMed] 
43. Al Amri, W.S.; Allinson, L.M.; Baxter, D.E.; Bell, S.M.; Hanby, A.M.; Jones, S.J.; Shaaban, A.M.; Stead, L.F.; Verghese, E.T.; Hughes, T.A. Genomic and expression analyses define MUC17 and PCNX1 as predictors of chemotherapy response in breast cancer. Mol. Cancer Ther. 2019, 19, 945-955. [CrossRef] [PubMed]

44. Zhang, J.Y. Chapter 15-Animal Models of Skin Disorders; Conn, P.M.B.T.-A.M., Ed.; Academic Press: Cambridge, MA, USA, 2017; pp. 357-375. [CrossRef]

45. Romieu, I.; Biessy, C.; Torres-Mejía, G.; Ángeles-Llerenas, A.; Sánchez, G.I.; Borrero, M.; Ossa, C.A.; Porras, C.; Rodríguez, A.C.; Ocampo, R.; et al. Project profile: A multicenter study on breast cancer in young women in Latin America (PRECAMA study). Salud Pública de México 2019, 61, 601-608. [CrossRef]

46. De Marini, D.M.; Landi, S.; Tian, D.; Hanley, N.M.; Li, X.; Hu, F.; Roop, B.C.; Mass, M.J.; Keohavong, P.; Gao, W.; et al. Lung tumor KRAS and TP53 mutations in nonsmokers reflect exposure to PAH-rich coal combustion emissions. Cancer Res. 2001, 61, 6679-6681.

47. Lee, D.G.; Burstyn, I.; Lai, A.S.; Grundy, A.; Friesen, M.C.; Aronson, K.J.; Spinelli, J.J. Women's occupational exposure to polycyclic aromatic hydrocarbons and risk of breast cancer. Occup. Environ. Med. 2019, 76, 22-29. [CrossRef] [PubMed]

48. A Petralia, S.; E Vena, J.; Freudenheim, J.L.; Dosemeci, M.; Michalek, A.; Goldberg, M.S.; Brasure, J.; Graham, S. Risk of premenopausal breast cancer in association with occupational exposure to polycyclic aromatic hydrocarbons and benzene. Scand. J. Work. Environ. Health 1999, 25, 215-221. [CrossRef]

49. Nallanthighal, S.; Heiserman, J.P.; Cheon, D.-J. The role of the extracellular matrix in cancer stemness. Front. Cell Dev. Biol. 2019, 7, 86. [CrossRef]

50. Shao, X.; Lv, N.; Liao, J.; Long, J.; Xue, R.; Ai, N.; Xu, D.; Fan, X. Copy number variation is highly correlated with differential gene expression: A pan-cancer study. BMC Med Genet. 2019, 20, 175. [CrossRef]

51. Shelling, A.N.; Cooke, I.E.; Ganesan, T.S. The genetic analysis of ovarian cancer. Br. J. Cancer 1995, 72, 521-527. [CrossRef] [PubMed]

52. Noviello, C.; Courjal, F.; Theillet, C. Loss of heterozygosity on the long arm of chromosome 6 in breast cancer: Possibly four regions of deletion. Clin. Cancer Res. 1996, 2, 1601-1606.

53. Bièche, I.; Khodja, A.; Driouch, K.; Lidereau, R. Genetic alteration mapping on chromosome 7 in primary breast cancer. Clin. Cancer Res. 1997, 3, 1009-1016.

54. Kang, J.U. Characterization of amplification patterns and target genes on the short arm of chromosome 7 in early-stage lung adenocarcinoma. Mol. Med. Rep. 2013, 8, 1373-1378. [CrossRef]

55. Nakamura, M.; Yang, F.; Fujisawa, H.; Yonekawa, Y.; Kleihues, P.; Ohgaki, H. Loss of heterozygosity on chromosome 19 in secondary glioblastomas. J. Neuropathol. Exp. Neurol. 2000, 59, 539-543. [CrossRef]

56. Bargou, R.C.; Wagener, C.; Bommert, K.; Mapara, M.Y.; Daniel, P.T.; Arnold, W.; Dietel, M.; Guski, H.; Feller, A.; Royer, H.D.; et al. Overexpression of the death-promoting gene bax-alpha which is downregulated in breast cancer restores sensitivity to different apoptotic stimuli and reduces tumor growth in SCID mice. J. Clin. Investig. 1996, 97, 2651-2659. [CrossRef]

57. Wong, R.S.Y. Apoptosis in cancer: From pathogenesis to treatment. J. Exp. Clin. Cancer Res. 2011, 30, 87. [CrossRef]

58. Castells, A.; Gusella, J.F.; Ramesh, V.; Rustgi, A.K. A region of deletion on chromosome 22q13 is common to human breast and colorectal cancers. Cancer Res. 2000, 60, 2836-2839. [PubMed]

59. Ghaffari, K.; Hashemi, M.; Ebrahimi, E.; Shirkoohi, R. BIRC5 Genomic Copy Number Variation in Early-Onset Breast Cancer. Iran. Biomed. J. 2016, 20, 241-245.

60. Wee, Y.; Liu, Y.; Lu, J.; Li, X.; Zhao, M. Identification of novel prognosis-related genes associated with cancer using integrative network analysis. Sci. Rep. 2018, 8, 3233. [CrossRef] [PubMed]

61. Kennedy, S.M.; O’Driscoll, L.; Purcell, R.; Fitz-Simons, N.; McDermott, E.W.; Hill, A.D.; O’Higgins, N.J.; Parkinson, M.; Linehan, R.; Clynes, M. Prognostic importance of survivin in breast cancer. Br. J. Cancer 2003, 88, 1077-1083. [CrossRef]

62. Dakal, T.C.; Kala, D.; Dhiman, G.; Yadav, V.; Krokhotin, A.; Dokholyan, N.V. Predicting the functional consequences of nonsynonymous single nucleotide polymorphisms in IL8 gene. Sci. Rep. 2017, 7, 6525. [CrossRef]

63. Zaiss, D.M.; van Loosdregt, J.; Gorlani, A.; Bekker, C.P.; Gröne, A.; Sibilia, M.; Henegouwen, P.M.V.B.E.; Roovers, R.C.; Coffer, P.J.; Sijts, A.J. Amphiregulin Enhances Regulatory T Cell-Suppressive Function via the Epidermal Growth Factor Receptor. Immunity 2013, 38, 275-284. [CrossRef]

64. Chang, C.-J.; Yin, P.-H.; Yang, D.-M.; Wang, C.-H.; Hung, W.-Y.; Chi, C.-W.; Wei, Y.-H.; Lee, H.-C. Mitochondrial dysfunctioninduced amphiregulin upregulation mediates chemo-resistance and cell migration in HepG2 cells. Cell. Mol. Life Sci. 2009, 66, 1755-1765. [CrossRef]

65. Ahsan, H.; Halpern, J.; Kibriya, M.G.; Pierce, B.L.; Tong, L.; Gamazon, E.; McGuire, V.; Felberg, A.; Shi, J.; Jasmine, F.; et al. A Genome-wide Association Study of Early-Onset Breast Cancer Identifies PFKM as a Novel Breast Cancer Gene and Supports a Common Genetic Spectrum for Breast Cancer at Any Age. Cancer Epidemiol. Biomark. Prev. 2014, 23, 658-669. [CrossRef]

66. Kuo, S.-H.; Yang, S.-Y.; You, S.-L.; Lien, H.-C.; Lin, C.-H.; Lin, P.-H.; Huang, C.-S. Polymorphisms of ESR1, UGT1A1, HCN1, MAP3K1 and CYP2B6 are associated with the prognosis of hormone receptor-positive early breast cancer. Oncotarget 2017, 8, 20925-20938. [CrossRef] [PubMed]

67. Ouni, N.; Ben Chaaben, A.; Kablouti, G.; Lajnef, M.; Ayari, F.; Abaza, H.; Damak, T.; Harzallah, L.; Benammar-Elgaaeid, A.; Guemira, F.; et al. MICA-129Met/Val Polymorphism Is Associated with Early-Onset Breast Cancer Risk. Immunol. Investig. 2017, 46, 603-614. [CrossRef] 
68. Anders, C.K.; Fan, C.; Parker, J.S.; Carey, L.A.; Blackwell, K.L.; Klauber-Demore, N.; Perou, C.M. Breast carcinomas arising at a young age: Unique biology or a surrogate for aggressive intrinsic subtypes? J. Clin. Oncol. 2011, 29, e18-e20. [CrossRef]

69. Azim, H.H.A.; Michiels, S.; Bedard, P.L.; Singhal, S.K.; Criscitiello, C.; Ignatiadis, M.; Haibe-Kains, B.; Piccart-Gebhart, M.; Sotiriou, C.; Loi, S. Elucidating Prognosis and Biology of Breast Cancer Arising in Young Women Using Gene Expression Profiling. Clin. Cancer Res. 2012, 18, 1341-1351. [CrossRef]

70. Yau, C.; Fedele, V.; Roydasgupta, R.; Fridlyand, J.; Hubbard, A.; Gray, J.W.; Chew, K.; Dairkee, S.H.; Moore, D.H.; Schittulli, F.; et al. Aging impacts transcriptomes but not genomes of hormone-dependent breast cancers. Breast Cancer Res. 2007, 9, R59. [CrossRef]

71. Schmucker, H.; Blanding, W.M.; Mook, J.M.; Wade, J.F.; Park, J.P.; Kwist, K.; Shah, H.; Booth, B.W. Amphiregulin regulates proliferation and migration of HER2-positive breast cancer cells. Cell. Oncol. 2017, 41, 159-168. [CrossRef]

72. Lamarca, H.L.; Rosen, J.M. Estrogen regulation of mammary gland development and breast cancer: Amphiregulin takes center stage. Breast Cancer Res. 2007, 9, 304. [CrossRef]

73. Baillo, A.; Giroux, C.; Ethier, S.P. Knock-down of amphiregulin inhibits cellular invasion in inflammatory breast cancer. J. Cell. Physiol. 2011, 226, 2691-2701. [CrossRef]

74. Sato, N.; Parker, A.R.; Fukushima, N.; Miyagi, Y.; A Iacobuzio-Donahue, C.; Eshleman, J.R.; Goggins, M. Epigenetic inactivation of TFPI-2 as a common mechanism associated with growth and invasion of pancreatic ductal adenocarcinoma. Oncogene 2004, 24, 850-858. [CrossRef] [PubMed]

75. Xu, C.; Wang, H.; He, H.; Zheng, F.; Chen, Y.; Zhang, J.; Lin, X.; Ma, D.; Zhang, H. Low expression of TFPI-2 associated with poor survival outcome in patients with breast cancer. BMC Cancer 2013, 13, 118. [CrossRef] [PubMed]

76. Hu, Y.-T.; Li, B.-F.; Zhang, P.-J.; Wu, D.; Li, Y.-Y.; Li, Z.-W.; Shen, L.; Dong, B.; Gao, J.; Zhu, X. Dbx2 exhibits a tumor-promoting function in hepatocellular carcinoma cell lines via regulating Shh-Gli1 signaling. World J. Gastroenterol. 2019, 25, 923-940. [CrossRef]

77. Yousef, G.M.; Scorilas, A.; Kyriakopoulou, L.G.; Rendl, L.; Diamandis, M.; Ponzone, R.; Biglia, N.; Giai, M.; Roagna, R.; Sismondi, P.; et al. Human kallikrein gene 5 (KLK5) expression by quantitative PCR: An independent indicator of poor prognosis in breast cancer. Clin. Chem. 2002, 48, 1241-1250. [CrossRef] [PubMed]

78. Król, M.B.; Galicki, M.; Grešner, P.; Wieczorek, E.; Jabłonska, E.; Reszka, E.; Morawiec, Z.; Wąsowicz, W.; Gromadzinska, J. ESR1 and GPX1 genes expression level in human malignant and non-malignant breast tissues. Acta Biochim. Pol. 2018, 65, 51-57. [CrossRef]

79. Yu, W.; Chai, H.; Li, Y.; Zhao, H.; Xie, X.; Zheng, H.; Wang, C.; Wang, X.; Yang, G.; Cai, X.; et al. Increased expression of CYP4Z1 promotes tumor angiogenesis and growth in human breast cancer. Toxicol. Appl. Pharmacol. 2012, 264, 73-83. [CrossRef] [PubMed]

80. Jiang, M.; Qiu, N.; Xia, H.; Liang, H.; Li, H.; Ao, X. Long non-coding RNA FOXD2-AS1/miR-150-5p/PFN2 axis regulates breast cancer malignancy and tumorigenesis. Int. J. Oncol. 2019, 54, 1043-1052. [CrossRef]

81. Rae, J.M.; Johnson, M.D.; Scheys, J.O.; Cordero, K.E.; Larios, J.M.; Lippman, M.E. GREB1 is a critical regulator of hormone dependent breast cancer growth. Breast Cancer Res. Treat. 2005, 92, 141-149. [CrossRef]

82. Wang, Y.; Lei, R.; Zhuang, X.; Zhang, N.; Pan, H.; Li, G.; Hu, J.; Pan, X.; Tao, Q.; Fu, D.; et al. DLC1-dependent parathyroid hormone-like hormone inhibition suppresses breast cancer bone metastasis. J. Clin. Investig. 2014, 124, 1646-1659. [CrossRef]

83. He, N.; Zheng, H.; Li, P.; Zhao, Y.; Zhang, W.; Song, F.; Chen, K. miR-485-5p binding site SNP rs8752 in HPGD gene is associated with breast cancer risk. PLoS ONE 2014, 9, e102093. [CrossRef]

84. Rakha, E.A.; Reis-Filho, J.S.; Ellis, I.O. Basal-like breast cancer: A critical review. J. Clin. Oncol. 2008, 26, 2568-2581. [CrossRef]

85. Turner, N.; Pearson, A.; Sharpe, R.; Lambros, M.; Geyer, F.; Lopez-Garcia, M.A.; Natrajan, R.; Marchio, C.; Iorns, E.; Mackay, A.; et al. FGFR1 amplification drives endocrine therapy resistance and is a therapeutic target in breast cancer. Cancer Res. 2010, 70, 2085-2094. [CrossRef]

86. Branchi, V.; García, S.A.; Radhakrishnan, P.; Győrffy, B.; Hissa, B.; Schneider, M.; Reißfelder, C.; Schölch, S. Prognostic value of DLGAP5 in colorectal cancer. Int. J. Color. Dis. 2019, 34, 1455-1465. [CrossRef]

87. Yu, Z.; He, Q.; Xu, G. Screening of prognostic factors in early-onset breast cancer. Technol. Cancer Res. Treat. 2020, 19, 1533033819893670. [CrossRef]

88. Jiang, W.G.; Douglas-Jones, A.; Mansel, R.E. Expression of peroxisome-proliferator activated receptor-gamma (PPAR $\gamma)$ and the PPAR $\gamma$ co-activator, PGC-1, in human breast cancer correlates with clinical outcomes. Int. J. Cancer 2003, 106, 752-757. [CrossRef]

89. D'Arcy, M.; Fleming, J.; Robinson, W.R.; Kirk, E.L.; Perou, C.M.; Troester, M.A. Race-associated biological differences among Luminal A breast tumors. Breast Cancer Res. Treat. 2015, 152, 437-448. [CrossRef]

90. van Schooneveld, E.; Wildiers, H.; Vergote, I.; Vermeulen, P.B.; Dirix, L.Y.; van Laere, S.J. Dysregulation of microRNAs in breast cancer and their potential role as prognostic and predictive biomarkers in patient management. Breast Cancer Res. 2015, 17, 21. [CrossRef]

91. Peña-Chilet, M.; Martínez, M.T.; A Pérez-Fidalgo, J.; Peiró-Chova, L.; Oltra, S.S.; Tormo, E.; Alonso-Yuste, E.; Martinez-Delgado, B.; Eroles, P.; Climent, J.; et al. MicroRNA profile in very young women with breast cancer. BMC Cancer 2014, 14, 529. [CrossRef]

92. Bastos, E.P.; Brentani, H.; Pereira, C.A.B.; Polpo, A.; Lima, L.; Puga, R.D.; Pasini, F.S.; Osorio, C.A.B.T.; Roela, R.A.; Achatz, M.I.; et al. A Set of miRNAs, Their Gene and Protein Targets and Stromal Genes Distinguish Early from Late Onset ER Positive Breast Cancer. PLoS ONE 2016, 11, e0154325. [CrossRef] 
93. Gravgaard, K.H.; Lyng, M.B.; Laenkholm, A.-V.; Søkilde, R.; Nielsen, B.S.; Litman, T.; Ditzel, H.J. The miRNA-200 family and miRNA-9 exhibit differential expression in primary versus corresponding metastatic tissue in breast cancer. Breast Cancer Res. Treat. 2012, 134, 207-217. [CrossRef]

94. Selcuklu, S.D.; Donoghue, M.T.A.; Rehmet, K.; Gomes, M.D.S.; Fort, A.; Kovvuru, P.; Muniyappa, M.K.; Kerin, M.J.; Enright, A.J.; Spillane, C. MicroRNA-9 inhibition of cell proliferation and identification of novel miR-9 targets by transcriptome profiling in breast cancer cells. J. Biol. Chem. 2012, 287, 29516-29528. [CrossRef]

95. Radojicic, J.; Zaravinos, A.; Vrekoussis, T.; Kafousi, M.; Spandidos, D.A.; Stathopoulos, E.N. MicroRNA expression analysis in triple-negative (ER, PR and Her2/neu) breast cancer. Cell Cycle 2011, 10, 507-517. [CrossRef]

96. Quero, L.; Dubois, L.; Lieuwes, N.G.; Hennequin, C.; Lambin, P. miR-210 as a marker of chronic hypoxia, but not a therapeutic target in prostate cancer. Radiother. Oncol. 2011, 101, 203-208. [CrossRef]

97. You, F.; Luan, H.; Sun, D.; Cui, T.; Ding, P.; Tang, H.; Sun, D. miRNA-106a promotes breast cancer cell proliferation, clonogenicity, migration, and invasion through inhibiting apoptosis and chemosensitivity. DNA Cell Biol. 2019, 38, 198-207. [CrossRef]

98. Zheng, R.; Pan, L.; Gao, J.; Ye, X.; Chen, L.; Zhang, X.; Tang, W.; Zheng, W. Prognostic value of miR-106b expression in breast cancer patients. J. Surg. Res. 2015, 195, 158-165. [CrossRef] [PubMed]

99. Fonseca-Sanchéz, M.A.; Fernández-Retana, J.; Aréchaga-Ocampo, E.; Marchat, L.A.; Bautista-Pina, V.; Arellano-Anaya, Z.E.; Flores-Pérez, A.; Perez-Plasencia, C.; Rodriguez-Cuevas, S.; Díaz-Chavez, J.; et al. microRNA-18b is upregulated in breast cancer and modulates genes involved in cell migration. Oncol. Rep. 2013, 30, 2399-2410. [CrossRef]

100. Lin, Y.; Liu, A.Y.; Fan, C.; Zheng, H.; Li, Y.; Zhang, C.; Wu, S.; Yu, D.; Huang, Z.; Liu, F.; et al. MicroRNA-33b inhibits breast cancer metastasis by targeting HMGA2, SALL4 and Twist1. Sci. Rep. 2015, 5, 9995. [CrossRef] [PubMed]

101. Gan, L.; Yang, H.; Xiong, Z.; Yang, Z.; Wang, T.; Lyu, G. miR-518a-3p Suppresses Triple-Negative Breast Cancer Invasion and Migration Through Regulation of TMEM2. Technol. Cancer Res. Treat. 2020, 19, 1533033820977523. [CrossRef]

102. Cheng, X.; Chen, J.; Huang, Z. miR-372 promotes breast cancer cell proliferation by directly targeting LATS2. Exp. Ther. Med. 2018, 15, 2812-2817. [CrossRef] [PubMed]

103. Lin, L.; Liu, D.; Liang, H.; Xue, L.; Su, C.; Liu, M. MiR-1228 promotes breast cancer cell growth and metastasis through targeting SCAI protein. Int. J. Clin. Exp. Pathol. 2015, 8, 6646-6655.

104. Zhang, Y.; Dai, J.; Deng, H.; Wan, H.; Liu, M.; Wang, J.; Li, S.; Li, X.; Tang, H. miR-1228 promotes the proliferation and metastasis of hepatoma cells through a p53 forward feedback loop. Br. J. Cancer 2014, 112, 365-374. [CrossRef] [PubMed]

105. Sand, M.; Skrygan, M.; Sand, D.; Georgas, D.; Hahn, S.A.; Gambichler, T.; Altmeyer, P.; Bechara, F. Expression of microRNAs in basal cell carcinoma. Br. J. Dermatol. 2012, 167, 847-855. [CrossRef] [PubMed]

106. Wu, D.; Wang, S.; Wen, X.; Han, X.; Wang, Y.; Fan, S.; Zhang, Z.; Shan, Q.; Lu, J.; Zheng, Y. Retracted: MircoRNA-1275 promotes proliferation, invasion and migration of glioma cells via SERPINE1. J. Cell. Mol. Med. 2018, 22, 4963-4974. [CrossRef]

107. Azimi, I.; Petersen, R.M.; Thompson, E.W.; Roberts-Thomson, S.J.; Monteith, G.R. Hypoxia-induced reactive oxygen species mediate N-cadherin and SERPINE1 expression, EGFR signalling and motility in MDA-MB-468 breast cancer cells. Sci. Rep. 2017, 7, 1-11. [CrossRef]

108. Pang, L.; You, L.; Ji, C.-B.; Shi, C.; Chen, L.; Yang, L.; Huang, F.; Zhou, Y.; Zhang, J.; Chen, X.; et al. miR-1275 inhibits adipogenesis via ELK1 and its expression decreases in obese subjects. J. Mol. Endocrinol. 2016, 57, 33-43. [CrossRef] [PubMed]

109. Raitoharju, E.; Seppälä, I.; Oksala, N.; Lyytikäinen, L.; Raitakari, O.; Viikari, J.; Ala-Korpela, M.; Soininen, P.; Kangas, A.J.; Waldenberger, M.; et al. Blood microRNA profile associates with the levels of serum lipids and metabolites associated with glucose metabolism and insulin resistance and pinpoints pathways underlying metabolic syndrome: The cardiovascular risk in Young Finns Study. Mol. Cell. Endocrinol. 2014, 391, 41-49. [CrossRef]

110. Liu, F.; Sang, M.; Meng, L.; Gu, L.; Liu, S.; Li, J.; Geng, C. miR-92b promotes autophagy and suppresses viability and invasion in breast cancer by targeting EZH2. Int. J. Oncol. 2018, 53, 1505-1515. [CrossRef] [PubMed]

111. Zhang, H.-D.; Sun, D.-W.; Mao, L.; Zhang, J.; Jiang, L.-H.; Li, J.; Wu, Y.; Ji, H.; Chen, W.; Wang, J.; et al. MiR-139-5p inhibits the biological function of breast cancer cells by targeting Notch1 and mediates chemosensitivity to docetaxel. Biochem. Biophys. Res. Commun. 2015, 465, 702-713. [CrossRef]

112. Hironaka-Mitsuhashi, A.; Otsuka, K.; Gailhouste, L.; Calle, A.S.; Kumazaki, M.; Yamamoto, Y.; Fujiwara, Y.; Ochiya, T. MiR-12855p/TMEM194A axis affects cell proliferation in breast cancer. Cancer Sci. 2020, 111, 395. [CrossRef] [PubMed]

113. Cheng, Y.; Xiang, G.; Meng, Y.; Dong, R. MiRNA-183-5p promotes cell proliferation and inhibits apoptosis in human breast cancer by targeting the PDCD4. Reprod. Biol. 2016, 16, 225-233. [CrossRef] [PubMed]

114. Yang, F.; Xiao, Z.; Zhang, S. Knockdown of miR-194-5p inhibits cell proliferation, migration and invasion in breast cancer by regulating the Wnt/ $\beta$-catenin signaling pathway. Int. J. Mol. Med. 2018, 42, 3355-3363. [CrossRef]

115. Qu, Y.; Dang, S.; Hou, P. Gene methylation in gastric cancer. Clin. Chim. Acta 2013, 424, 53-65. [CrossRef]

116. Oltra, S.S.; Peña-Chilet, M.; Flower, K.; Martinez, M.T.; Alonso, E.; Burgues, O.; Lluch, A.; Flanagan, J.M.; Ribas, G. Acceleration in the DNA methylation age in breast cancer tumours from very young women. Sci. Rep. 2019, 9, 14991. [CrossRef]

117. $\mathrm{Xu}, \mathrm{J} . ; \mathrm{Wu}, \mathrm{D}$.; Wang, S.; Wang, Z. MAT2B expression correlates with poor prognosis in triple-negative breast cancer. Cancer Manag. Res. 2019, 11, 5501-5511. [CrossRef]

118. Gautam, J.; Banskota, S.; Lee, H.; Lee, Y.-J.; Jeon, Y.H.; Kim, J.-A.; Jeong, B.-S. Down-regulation of cathepsin S and matrix metalloproteinase-9 via Src, a non-receptor tyrosine kinase, suppresses triple-negative breast cancer growth and metastasis. Exp. Mol. Med. 2018, 50, 1-14. [CrossRef] [PubMed] 
119. Hosoda, M.; Yamamoto, M.; Nakano, K.; Hatanaka, K.C.; Takakuwa, E.; Hatanaka, Y.; Matsuno, Y.; Yamashita, H. Differential expression of progesterone receptor, FOXA1, GATA3, and p53 between pre- and postmenopausal women with estrogen receptorpositive breast cancer. Breast Cancer Res. Treat. 2014, 144, 249-261. [CrossRef]

120. Ward, A.; Shukla, K.; Balwierz, A.; Soons, Z.; König, R.; Sahin, Ö.; Wiemann, S. MicroRNA -519a is a novel oncomir conferring tamoxifen resistance by targeting a network of tumour-suppressor genes in ER + breast cancer. J. Pathol. 2014, 233, 368-379. [CrossRef] [PubMed]

121. Green, A.R.; Caracappa, D.; Benhasouna, A.A.; Alshareeda, A.; Nolan, C.C.; Macmillan, R.D.; Madhusudan, S.; Ellis, I.O.; Rakha, E.A. Biological and clinical significance of PARP1 protein expression in breast cancer. Breast Cancer Res. Treat. 2015, 149, 353-362. [CrossRef]

122. Davis, J.M.; Navolanic, P.M.; Weinstein-Oppenheimer, C.R.; Steelman, L.S.; Hu, W.; Konopleva, M.; Blagosklonny, M.V.; A McCubrey, J. Raf-1 and Bcl-2 induce distinct and common pathways that contribute to breast cancer drug resistance. Clin. Cancer Res. 2003, 9, 1161-1170. [PubMed]

123. Martínez-Galán, J.; Torres-Torres, B.; Núñez, M.I.; López-Peñalver, J.; Del Moral, R.; De Almodóvar, J.M.R.; Menjón, S.; Concha, Á.; Chamorro, C.; Ríos, S.; et al. ESR1gene promoter region methylation in free circulating DNA and its correlation with estrogen receptor protein expression in tumor tissue in breast cancer patients. BMC Cancer 2014, 14, 59. [CrossRef] [PubMed]

124. Coleman, L.J.; Peter, M.B.; Teall, T.J.; A Brannan, R.; Hanby, A.M.; Honarpisheh, H.; Shaaban, A.M.; Smith, L.; Speirs, V.; Verghese, E.T.; et al. Combined analysis of eIF4E and 4E-binding protein expression predicts breast cancer survival and estimates eIF4E activity. Br. J. Cancer 2009, 100, 1393-1399. [CrossRef] [PubMed]

125. Peck, A.R.; Witkiewicz, A.K.; Liu, C.; Klimowicz, A.C.; A Stringer, G.; Pequignot, E.; Freydin, B.; Yang, N.; Ertel, A.; Tran, T.H.; et al. Low levels of Stat5a protein in breast cancer are associated with tumor progression and unfavorable clinical outcomes. Breast Cancer Res. 2012, 14, R130. [CrossRef] [PubMed]

126. Prest, S.J.; May, F.E.B.; Westley, B.R. The estrogen-regulated protein, TFF1, stimulates migration of human breast cancer cells. FASEB J. 2002, 16, 592-594. [CrossRef]

127. A Azim, H.; A Peccatori, F.; Brohée, S.; Branstetter, D.; Loi, S.; Viale, G.; Piccart, M.; Dougall, W.C.; Pruneri, G.; Sotiriou, C. RANK-ligand (RANKL) expression in young breast cancer patients and during pregnancy. Breast Cancer Res. 2015, 17, 24. [CrossRef] [PubMed]

128. Trabert, B.; Sherman, M.E.; Kannan, N.; Stanczyk, F.Z. Progesterone and Breast Cancer. Endocr. Rev. 2020, 41, 320-344. [CrossRef] [PubMed]

129. Colak, D.; Nofal, A.; AlBakheet, A.; Nirmal, M.; Jeprel, H.; Eldali, A.; Al-Tweigeri, T.; Tulbah, A.; Ajarim, D.; Al Malik, O.; et al. Age-Specific Gene Expression Signatures for Breast Tumors and Cross-Species Conserved Potential Cancer Progression Markers in Young Women. PLoS ONE 2013, 8, e63204. [CrossRef]

130. Xu, J.; Chen, Y.; Olopade, O.I. MYC and Breast Cancer. Genes Cancer 2010, 1, 629-640. [CrossRef]

131. Aoudjit, F.; Vuori, K. Integrin signaling inhibits paclitaxel-induced apoptosis in breast cancer cells. Oncogene 2001, 20, 4995-5004. [CrossRef] [PubMed]

132. Huang, C.; Park, C.C.; Hilsenbeck, S.G.; Ward, R.; Rimawi, M.F.; Wang, Y.-C.; Shou, J.; Bissell, M.J.; Osborne, C.K.; Schiff, R. $\beta 1$ integrin mediates an alternative survival pathway in breast cancer cells resistant to lapatinib. Breast Cancer Res. 2011, 13, R84. [CrossRef] [PubMed]

133. Taherian, A.; Li, X.; Liu, Y.; A Haas, T. Differences in integrin expression and signaling within human breast cancer cells. BMC Cancer 2011, 11, 1-15. [CrossRef]

134. Vieira, A.F.; Ribeiro, A.S.; Dionísio, M.R.; Sousa, B.; Nobre, A.R.; Albergaria, A.; Santiago-Gómez, A.; Mendes, N.; Gerhard, R.; Schmitt, F.; et al. P-cadherin signals through the laminin receptor $\alpha 6 \beta 4$ integrin to induce stem cell and invasive properties in basal-like breast cancer cells. Oncotarget 2014, 5, 679-692. [CrossRef] [PubMed]

135. Gee, J.; Robertson, J.F.; Gutteridge, E.; O Ellis, I.; E Pinder, S.; Rubini, M.; I Nicholson, R. Epidermal growth factor receptor/HER2/insulin-like growth factor receptor signalling and oestrogen receptor activity in clinical breast cancer. Endocr. Relat. Cancer 2005, 12, S99-S111. [CrossRef]

136. Arneth, B. Tumor Microenvironment. Medicina 2019, 56, 15. [CrossRef]

137. Azim, H.A.; Nguyen, B.; Azim, H.A., Jr. Young Age and Breast Cancer Biology. In Breast Cancer in Young Women; Springer: Berlin/Heidelberg, Germany, 2020; pp. 13-22.

138. Pang, L.; Qiu, T.; Cao, X.; Wan, M. Apoptotic role of TGF- $\beta$ mediated by Smad4 mitochondria translocation and cytochrome $c$ oxidase subunit II interaction. Exp. Cell Res. 2011, 317, 1608-1620. [CrossRef] [PubMed]

139. Chandra, D.; Liu, J.-W.; Tang, D.G. (Eds.) Early mitochondrial activation and cytochrome c up-regulation during apoptosis. Early mitochondrial activation and cytochrome c up-regulation during apoptosis. J. Biol. Chem. 2002, 277, 50842-50854. [CrossRef] [PubMed]

140. Marcato, P.; Dean, C.A.; Pan, D.; Araslanova, R.; Gillis, M.; Joshi, M.; Helyer, L.; Pan, L.; Leidal, A.; Gujar, S.; et al. Aldehyde Dehydrogenase Activity of Breast Cancer Stem Cells Is Primarily Due To Isoform ALDH1A3 and Its Expression Is Predictive of Metastasis. Stem Cells 2011, 29, 32-45. [CrossRef] [PubMed]

141. Zhang, Q.; Gu, J.; Li, L.; Liu, J.; Luo, B.; Cheung, H.-W.; Boehm, J.S.; Ni, M.; Geisen, C.; Root, D.E.; et al. Control of Cyclin D1 and Breast Tumorigenesis by the EgIN2 Prolyl Hydroxylase. Cancer Cell 2009, 16, 413-424. [CrossRef]

142. Sachdev, D.; Yee, D. The IGF system and breast cancer. Endocr. Relat. Cancer 2001, 8, 197-209. [CrossRef] 
143. Blanas, A.; Sahasrabudhe, N.M.; Rodríguez, E.; Van Kooyk, Y.; Van Vliet, S.J. Fucosylated antigens in cancer: An alliance toward tumor progression, metastasis, and resistance to chemotherapy. Front. Oncol. 2018, 8, 39. [CrossRef]

144. Eastlack, S.C.; Dong, S.; Ivan, C.; Alahari, S.K. Suppression of PDHX by microRNA-27b deregulates cell metabolism and promotes growth in breast cancer. Mol. Cancer 2018, 17, 1-16. [CrossRef]

145. Chen, J.; Yao, Y.; Gong, C.; Yu, F.; Su, S.; Chen, J.; Liu, B.; Deng, H.; Wang, F.; Lin, L.; et al. CCL18 from tumor-associated macrophages promotes breast cancer metastasis via PITPNM3. Cancer Cell 2011, 19, 541-555. [CrossRef] [PubMed]

146. Chang, J.-W.; Kuo, W.-H.; Lin, C.-M.; Chen, W.-L.; Chan, S.-H.; Chiu, M.-F.; Chang, I.-S.; Jiang, S.-S.; Tsai, F.-Y.; Chen, C.-H.; et al. Wild-type p53 upregulates an early onset breast cancer-associated gene GAS7 to suppress metastasis via GAS7-CYFIP1-mediated signaling pathway. Oncogene 2018, 37, 4137-4150. [CrossRef] [PubMed] 